\title{
EL DESPIDO LIBRE EN EL CONTRATO DE TRABAJO ESTADOUNIDENSE
}

\section{THE EMPLOYMENT AT WILL IN LABOR CONTRACT IN AMERICAN}

Sergio Gamonal Contreras*

\section{RESUMEN}

Este artículo analiza el despido libre o empleo a voluntad en el contrato de trabajo en Estados Unidos, explicando sus orígenes, desarrollo y fundamentos, así como sus críticas por parte de diversos laboralistas de dicho país, finalizando con algunas conclusiones críticas desde la perspectiva de la teoría del Derecho del Trabajo.

Palabras clave: Empleo a voluntad, contrato de trabajo, libertad de contratación, justa causa y despido injustificado.

\section{ABStRACT}

This article analyzes the employment at will in the labor contract in United States, explaining its origins, development and foundations, as well as criticism from various american labour law professors, ending with some critical conclusions from the perspective of the theory of labor law.

Keywords: Employment at will, labor contract, freedom of contract, just cause and unfair dismissal.

\section{INTRODUCCIÓN}

Karen Bammer trabajó durante veintiséis años para Don's Super Valu, en el poblado de Menomonie, Wisconsin. Jamás tuvo problemas con su

* Licenciado en Ciencias Jurídicas y Sociales, Universidad de Chile. Profesor titular de Derecho del Trabajo, Universidad Adolfo Ibáñez, Avda. Diagonal Las Torres 2640 of. 202-B, Peñalolén, Santiago, Chile. Correo electrónico: sergio.gamonal@uai.cl. Artículo recibido el 20 de julio de 2015 y aceptado para su publicación el 11 de noviembre de 2016. 
empleador, Don Williams, hasta que el esposo de la señora Bammert, quien era oficial de policía, asistió al arresto de Nona, la esposa de Don Williams por conducir en estado de ebriedad. Frente a estos hechos, Don Williams despidió a la señora Bammer como represalia por el arresto y ella demandó por despido injustificado. Aunque los hechos estaban probados, la Corte Suprema de Wisconsin desestimó la demanda en el año 2002 y lo declaró válido ${ }^{1}$.

Michael Bullard era un trabajador blanco que fue despedido por apoyar los derechos de las personas negras en el lugar de trabajo. Se trataba del operador de un complejo de apartamentos donde el dueño utilizaba diversos subterfugios para negarse a alquilar a los negros, en violación de las leyes de derechos civiles. Cuando tres negros intentaron alquilar un apartamento y fueron violentamente amenazados por los guardias del empleador, Michael Bullard le habría comentado a un compañero de trabajo que "los negros también tienen derechos" 2 . Esta afirmación fue considerada por su supervisor como una actitud indeseada de "excesiva simpatía hacia los afroamericanos", una especie de "amante de los negros de mierda", lo que justificaba su despido. La Corte Suprema de Nevada decidió este caso en 1995 afirmando que, aunque estas acusaciones fueran ciertas, el despido era lícito ${ }^{3}$. Como señala Clyde Summers, la Corte no tuvo interés alguno en la autonomía o en las expresiones de la personalidad del trabajador despedido, frente a los intereses comerciales del empleador o sus caprichos personales ${ }^{4}$.

Melissa Nelson trabajó como asistente dental para el odontólogoJames Knight, por diez años antes de ser despedida en el año 2010, aun cuando en palabras de James Knight era una buena asistente. Él era veinte años mayor que ella y ambos estaban casados y tenían hijos. Sin embargo, el último año la conducta de James Knight empezó a cambiar, haciéndole comentarios sobre lo apretado de su ropa a su asistente, así como algunas insinuaciones sobre su apariencia física a las que ella no dio importancia, dado que lo veía como un padre y amigo. En las vacaciones de Navidad James Knight envió varios mensajes de texto (SMS) a Melissa Nelson y su esposa le exigió que la despidiera. Incluso, consultaron con el pastor principal de su Iglesia, quien les aconsejó que lo hicieran. Por ello, James Knight la llamó y en compañía de un pastor de su Iglesia la despidió, dándole un mes de sueldo y leyéndole una declaración en que afirmaba que su relación laboral se había vuelto perjudicial para su familia. Melissa

\footnotetext{
${ }^{1}$ Bammert v. Don'S (2002). Véase Moss (2005), pp. 299-300.

${ }^{2}$ Bigelow v. Bullard (1995). Véase McGinley (1996), p. 1493 n. 323.

${ }^{3}$ Summers (2001), p. 458.

${ }^{4}$ Op. cit., p. 459.
} 
Nelson lloró y dijo que amaba su trabajo, pero el despido fue concretado sin dilaciones. Luego, reunido por el esposo de Melissa, James declaró que Melissa Nelson no había hecho nada malo o inadecuado, pero James Knight temía que si ella seguía trabajando allí, él podría intentar tener una aventura con Melissa ${ }^{5}$. Ella demandó por discriminación y la Corte Suprema de Iowa afirmó en diciembre de 2012 que un empleador puede perfectamente despedir a una trabajadora por causas ajenas a ella (nunca le coqueteó), si la esposa del primero está preocupada de la relación de su marido con ella porque la ve como una "irresistible atracción" .

El impacto en la opinión pública fue intenso, el caso se conoció por internet y hubo artículos, debates y entrevistas en la TV consolidándose una opinión generalizada de injusticia respecto de Melissa Nelson y de indignación pública con la Corte ${ }^{7}$. Por ello, la Corte Suprema de Iowa revisó el caso en julio de 2013 y sin nuevos argumentos mantuvo su decisión, excusándose en las dificultades de definir discriminación por sexo en el lugar de trabajo ${ }^{8}$. Precisó, además, que la discriminación sexual debe probarse y, en caso contrario, lo que rige es la regla del empleo a voluntad ${ }^{9}$.

Varios decenios antes de estos tres casos, la Corte Suprema federal había dictaminado, a principios del siglo xx, que el empleador podía despedir lícitamente a los trabajadores que se sindicalizaran. En efecto, la ley Erdman de 1898, que prohibía a las empresas de transporte de ferrocarriles despedirlos por causas de su afiliación sindical, fue declarada inconstitucional en el 1908 en el caso Adair v. United States por la Corte Suprema federal ${ }^{10}$.

Cualquier lector no habituado al Derecho estadounidense del trabajo estará impactado con estas decisiones jurisdiccionales. Cómo es posible

${ }^{5}$ Nelson v. Knight (2013). Véase CoRbett (2013), pp. 25-26.

${ }^{6}$ Op. cit., pp. 27-28.

${ }^{7}$ Op. cit., p. 30.

${ }^{8}$ Op. cit., p. 31.

${ }^{9}$ Ibid.

${ }^{10}$ Adair v. United States, (1908). Véase Steidle (1999), p. 5. En dos casos siguientes se reafirmó esta tesis. En el primero, se declaró la inconstitucionalidad de una ley de Kansas, que prohibía que el empleador exigiera la promesas de no afiliarse al sindicato o de retirarse del mismo: Coppage v. Kansas, (1915). Véase Lambert (2010), pp. 94-95.

En el segundo, se validó una orden judicial para que la directiva sindical revelara los nombres de los sindicalizados para tomar las correspondientes represalias (despido) por parte del empleador: Hitchman v. Mitcheell, (1917). Op. cit., p. 95. Aunque estos criterios en materia de persecución sindical han cambiado desde la Ley Wagner, de 1935, donde se prohíbe despedir por motivos de sindicalización, estas sentencias de principios del novecientos de la Corte Suprema Federal de Estados Unidos son un antecedente relevante para lo que será el análisis del employment at will en este trabajo. Véase GAMONAL y RosAdo (2014a), p. 79 y ss. 
que se pueda despedir por represalia ante una actuación policial lícita, o porque se defiende la dignidad de personas de color, o porque una trabajadora es "irresistiblemente atractiva", se preguntará.

Lo que ocurre es que Estados Unidos tiene un sistema único de despido $^{11}$, el despido libre o employment at will(empleo a voluntad o despido libre) como se lo denomina en inglés ${ }^{12}$. En otras palabras, cualquiera de las partes puede terminar el contrato de trabajo sin preaviso, por cualquier motivo o sin motivo alguno, y sin tener que pagar ningún tipo de indemnización.

Como expresó la Corte Suprema de Wisconsin en el caso Bammert, el empleo a voluntad es central en una economía de mercado y sirve en interés de ambas partes (empleador y trabajador) porque maximiza la libertad de ambos $^{13}$. Señaló, además, que se puede despedir, incluso, cuando es injusto, desafortunado o duro ${ }^{14}$ y que generalmente los trabajadores pueden ser despedidos a voluntad del empleador por cualquier razón, sin causa o una mala causa, salvo que este sea ilegal ${ }^{15}$.

El employment at will tiene sus enemigos y defensores y en este artículo explicaremos los orígenes de esta doctrina, su desarrollo, así como sus límites (despido injustificado) y las críticas por parte de la doctrina y jurisprudencia estadounidense, para concluir con un análisis de sus méritos desde la óptica de la teoría del Derecho del Trabajo.

Considerando el caso de Estados Unidos y toda la discusión que ha rodeado a esta figura, argumentaremos en las conclusiones en favor de las normas que limitan el despido, como ocurre en todos los países desarrollados.

\section{ORÍGENES Y CONSOLIDACIÓN DE ESTA DOCTRINA}

Los sistemas de despido en los países desarrollados adoptan diversas modalidades. Por un lado, están los sistemas causados donde la regla es que el injustificado es nulo y debe reintegrarse al trabajador, como en Alemania o Italia ${ }^{16}$. Luego, están aquellos donde la generalidad de los casos conlleva que el despido injustificado no es nulo, pero el empleador debe hacerle un pago indemnizatorio como en Francia ${ }^{17}$. Asimismo, en otros sistemas

${ }^{11}$ Es un lugar común hacer presente que el Derecho estadounidense es único y excepcional en este sentido. Véase Estreicher y Cherry (2008), p. 56.

${ }^{12}$ Tanto en los sistemas de Common Law como de Civil Law existen normas que limitan el despido del trabajador. Véase Gamonal y Rosado (2014a), p. 25, n. 59.

${ }^{13}$ Moss (2005), p. 300.

${ }^{14}$ Corbett (2013), p. 42.

${ }^{15}$ Zimmer (2013), p. 18.

${ }^{16}$ Martínez y Arufe (2007), pp. 199-201.

${ }^{17}$ Op. cit., p. 202. 
existe una obligación de preaviso y su eventual indemnización en caso de incumplimiento, como en Canadá ${ }^{18}$ y Gran Bretaña ${ }^{19}$. Por último, está el sistema de despido libre de Estados Unidos, que permite terminar sin causa el contrato. Este último es un modelo de despido puro, donde el empresario ni siquiera debe preavisar al trabajador y menos pagar una indemnización ${ }^{20}$.

El sistema de preaviso británico, denominado también regla inglesa, fue aceptado en numerosas sentencias en Estados Unidos durante el siglo XIX, pese a que a fines del mismo los tribunales adoptaron la denominada regla americana del employment at will ${ }^{1}$.

Como se indicaba en el caso Bammert, el empleo a voluntad sostiene que las partes pueden terminar el contrato de trabajo en cualquier momento, por una buena causa, una mala causa o simplemente sin causa alguna. Es decir, no se exige una causa o causa justa para que termine. Por el contrario, la regla inglesa durante el siglo XIX presumía que la contratación de un trabajador era por un año, salvo que las partes hubieran acordado un plazo en forma expresa. Esta regla inglesa se fundaba en el sistema agrícola de producción. Durante el transcurso del siglo xix, lentamente esta regla fue evolucionando en el sentido de permitir el término del contrato indefinido con el debido preaviso ${ }^{22}$.

En 1877 Horace Gray Wood publica en Estados Unidos su tratado sobre Master-Servant, postulando la pertinencia de una regla distinta a la inglesa, la regla americana del despido libre. Desde $1880^{23}$ esta nueva regla empieza a ser reconocida en sentencias estadounidenses hasta que fue consolidada por la Corte Suprema Federal a principios del siglo $\mathrm{XX}^{24}$. Como veíamos a inicios de este trabajo, esta regla sigue vigente en todo Estados Unidos, en casos como Bammert, Bullard y Nelson.

La gran excepción a la regla es el Estado de Montana, el cual desde 1987 ha establecido por ley el despido por justa causa, derogando el $\mathrm{em}^{-}$ ployment at will ${ }^{25}$, y que examinaremos a continuación. Sin perjuicio de lo anterior, podemos mencionar, además, que el estado libre asociado de

${ }^{18}$ England (2008), p. 283 y ss.

${ }^{19}$ Deakin y Morris (2009), p. 351 y ss.

${ }^{20}$ Martínez y Arufe (2007), p. 207.

${ }^{21}$ Gamonal y Rosado (2014a), pp. 96-104.

${ }^{22}$ En Fairman v. Oaford (1860), el preaviso debía ser de tres meses. Véase Galiana (1978), pp. 207-209.

${ }^{23}$ Véase Payne v. Western (1884). Esta sentencia de la Suprema Corte de Tennessee es citada como la primera que adhiere en forma expresa a la tesis de Stephen Wood. Véase SсHWAв (1993), p. 8 n. 1.

${ }^{24}$ Véase Martínez (1988), pp. 130-131.

${ }^{25}$ Morriss (2007), p. 239 y ss. 
Puerto Rico e Islas Vírgenes (de Estados Unidos) tienen leyes sobre despido ilícito ${ }^{26}$. Por otro lado, en Dakota del Sur, aun cuando la ley consagra el empleo a voluntad establece algunas reglas en favor del trabajador. En efecto, si se pacta un plazo el empleo a voluntad no es aplicable. Además, el tiempo que las partes acuerdan para la estimación de los salarios es relevante para la determinación del periodo del contrato, si este no está especificado e, incluso, si no existe acuerdo o costumbre en cuanto a la duración del servicio, se presume que el trabajador ha sido contratado por un mes ${ }^{27}$.

En el caso de Montana, en 1987 se dictó la Montana Wrongful Discharge From Employment Act, estableciendo que el despido solo puede ser por justa causa. En la década del ochenta del siglo pasado, la Corte Suprema de Montana se alejó de la doctrina del despido libre (que estaba expresamente codificada) e interpretó en forma extensiva las excepciones e, incluso, hubo juicios en que decretó daños punitivos en casos de despido injustificado ${ }^{28}$. Esta tesis favorable al trabajador constituyó un incentivo para la aprobación de la ley en $1987^{29}$.

No obstante esta excepción de Montana y la regla inglesa, que fue aplicada hasta fines del siglo XIX, la regla general y predominante en Estados Unidos sigue siendo el empleo a voluntad. Las razones de este éxito no están del todo claras. Intuitivamente tiende a pensarse que la regla americana es una clara demostración del predominio de las lógicas del Derecho Privado por sobre el Derecho del Trabajo. Con todo, se ha sugerido que no es así. En efecto, antes de su consolidación los juzgados estadounidenses buscaban la real voluntad de las partes contratantes, con el fin de determinar si se había acordado un plazo o duración para esta relación ${ }^{30}$. Esta lógica es propia de la interpretación de los contratos civiles, como ocurre, por ejemplo, con el artículo 1560 del Código Civil

${ }^{26}$ McGinley (1996), pp. 1503-1506.

${ }^{27}$ Oviatt (1986), pp. 693-694. También se han ensayado mecanismos de mediación en caso de despido. Por ejemplo, en la década de 1980, en Carolina del Sur, el sistema de mediación voluntaria de la Comisión Estatal del Trabajo por término de contrato era bastante exitoso, considerando que la mitad de los casos fueron consensuados para cambiar los términos del despido y en el $40 \%$ se ha aceptó el reintegro del trabajador a sus labores. Al respecto, véase Bierman y Youngblood (1984), p. 38.

${ }^{28}$ Morriss (2007), p. 249.

${ }^{29}$ Las predicciones de los efectos económicos de esta ley fueron negativas, por suponerse que aumentaría el desempleo. Sin embargo, casi diez años desde su entrada en vigencia, la cesantía había bajado de 7,4\% en 1987 a 5,5\% en 1995. Véase McGinley (1996), pp. 1522-1523. Más tarde, casi veinte años desde su promulgación, los estudios señalaban la siguiente correlación (obviamente no se trata de causalidad): el empleo había crecido bajo la ley de justa causa en Montana. Véase EwING, NorTh, y TAYLOR (2005), p. 31.

${ }^{30}$ Feinman (1976), p. 129. 
chileno. Con el employment at will se presume el despido a voluntad y los tribunales ya no indagan acerca de la real voluntad de las partes ${ }^{31}$.

Aunque Stephen Wood en su libro enfatiza que el despido libre era la regla predominante que estaban ocupando los tribunales de la época, Jay Feinman ha hecho presente que no se trataba de una tendencia consolidada en 1877, dado que había numerosos casos decididos al tenor de la regla inglesa $^{32}$. De hecho, en dicha época la contratación laboral mayoritaria era por un año, sin empleo a voluntad ${ }^{33}$ y el autor del libro no justifica su aserción de que la nueva regla americana es seguida por los tribunales. Solo cita cuatro casos de jurisprudencia y ninguno es sobre despido libre (salvo tangencialmente) ${ }^{34}$, lo que parece increíble dado el éxito de su tesis. Desde inicios del siglo xx solo se citarán esos cuatro casos sin mayores razones o análisis por parte de los tribunales ${ }^{35}$.

La tesis de Stephen Wood se consolidó definitivamente con la sentencia de Nueva York denominada Martin v. New York Life Insurance en $1895^{36}$. Esta tendencia se expresaría luego a inicios del siglo xx con la sentencia de la Corte Suprema Federal Adair v. United States, citada anteriormente.

\section{El SURGIMIENTO DE LA TEORÍA DEL DESPIDO INJUSTIFICADO}

Salvo algunas excepciones legales ${ }^{37}$, el empleo a voluntad reinará sin contrapesos en el siglo xx hasta fines de la década de 1950. Desde esa época

${ }^{31}$ Feinman (1976), pp. 129-130.

${ }^{32}$ Op. cit., p. 130.

${ }^{33}$ Ibid.

${ }^{34}$ Shapiro y Tune (1974), p. 341 y n. 54

${ }^{35}$ Op. cit., p. 342 . Esta visión no es pacífica. Otros autores han hecho presente que había sentencias anteriores al tratado de Stephen Wood que aplicaban la que se conocería como regla americana y que este autor no se oponía a que el trabajador probara que se había acordado un término o plazo de duración. Véase Freed y Polsby (1990). Mayer Freed y Daniel Polsby concluyen que la regla fluyó naturalmente del capitalismo económico, op. cit., p. 558. En todo caso, es difícil aceptar este argumento, dado que ninguno de los países capitalistas, salvo Estados Unidos, ha adoptado esta regla.

${ }^{36}$ Martin v. New York, (1895). En Feinman (1976), p. 128. Pese a que había sentencias anteriores, la Corte Suprema de Nueva York y la de California suelen ser referentes en el ámbito federal. Algunos autores han estudiado las influencias entre Estados en cuanto a sus precedentes judiciales. Justamente en materia laboral sobre despido injusto, se ha documentado la influencia recíproca entre Estados sobre todo dentro de los circuitos federales. Véase BiRd y SMYthe (2008) pp. 856-860.

${ }^{37}$ Algunas leyes prohibían la persecución al trabajador y las represalias (retaliation), sancionando su despido, como la Ley Wagner y la Fair Labor Standard Act. Desde la década de 1970 lo mismo ocurrirá con la Ley de Derechos Civiles. Véase Gamonal y Rosado (2014a), p. 63 y ss. y EsTLund (1996), pp. 1658-1662. 
los tribunales estadounidenses empezarán a desarrollar una doctrina del despido abusivo que llega hasta nuestros días.

Como señala Paul Weiler, desde fines de la década de 1970 existen argumentos consistentes para limitar el employment at will. La experiencia demuestra que el empleador suele ocupar en forma abusiva su prerrogativa para despedir; la libertad de despido es cada vez más intensa dado que las personas necesitan su trabajo no solo para mantener a sus familias sino, también, para realizarse personalmente; la negociación libre entre las partes no es efectiva porque la mantención del trabajo es más relevante para el trabajador que para el empleador retener a un empleado $\mathrm{y}$, también, cabe considerar que existe un evidente contraste respecto de los trabajadores cubiertos por negociación colectiva, los cuales gozan del derecho a ser despedidos solo por justa causa, a diferencia de los que negocian individualmente ${ }^{38}$.

El caso líder en materia de despido injustificado fue decidido en $\mathrm{Ca}-$ lifornia en 1959, Pertemann v. Teamsters, donde se despidió a un trabajador por negarse a cometer perjurio en su favor en una investigación por actos ilegales $^{39}$. La Corte de Apelaciones californiana expresó que sería detestable para las políticas públicas y para los intereses del Estado permitir a un empleador despedir por negarse a cometer perjurio. Sostener lo contrario sería irrazonable y en contra del espíritu de las leyes penales de California ${ }^{40}$.

Que el despido pueda ser injustificado implica que se debe contar con una justa causa para poner término al contrato. Justa causa significa que se asegura al trabajador que la vinculación no finalizará de forma injusta o arbitraria, otorgándole de esta forma estabilidad en su empleo ${ }^{41}$.

La teoría del despido injustificado ha sido desarrollada desde esa época por distintos tribunales en los Estados estadounidenses. Podemos agrupar en cuatro los casos, a saber: excepción de orden público (desde 1959 en California), la excepción de buena fe (implied covenant of good faith) (desde 1974 en New Hampshire), la excepción del despido abusivo (desde 1976 en Massachusets) y la de cláusulas tácitas de estabilidad ( implied terms) (desde 1980 en Michigan). Las excepciones de orden público y de despido abusivo son extracontractuales (torts), y las de buena fe y cláusulas tácitas de responsabilidad contractual ${ }^{42}$. Estas excepciones se han extendido por la mayoría de los Estados de Estados Unidos confrontados

${ }^{38}$ WeILER (1993), pp. 49-50.

${ }^{39}$ Pertemann v. Teamsters, (1959), citado en Bierman y Youngblood (1984), p. 31.

${ }^{40} 174$ Cal. App. 2d 184, 29 Cal. Rptr. 399, 344 P.2d 25 (1959). Citado en Bierman y YoungBlOOD (1984), p. 31.

${ }^{41}$ Ray, Sharpe y STRAsSFEld (2011). p. 33.

${ }^{42}$ Edelman, Abraham y Erlanger (1992), p. 52. 
a los altos niveles de desempleo y a la cada vez más fuerte dependencia de la población respecto de las remuneraciones ${ }^{43}$.

La excepción de orden público implica que puede demandarse por despido injustificado (unfair dismissal) si lo ha sido por haberse negado a violar una ley, por ejercer sus derechos legales, o por adoptar otras acciones basadas en el interés público, o por reportar actividades ilegales (whistleblowing $)^{44}$.

La excepción de buena fe significa que el despido no puede ser de mala fe, por ejemplo, por negarse a tener una cita con su jefe o para no pagarle un bono al cual tendrá derecho ${ }^{45}$. Esta excepción es la menos aceptada en las jurisdicciones estatales, siendo aplicada solo en veintiún Estados ${ }^{46}$. Un caso de buena fe bastante citado en la literatura jurídica es Fortune. Se trataba de un vendedor comisionista despedido poco después de haber negociado una venta multimillonaria para su empleador. Como su comisión dependía de la venta, pero también de la supervisión de la instalación de los equipos, su comisión sería menor. Se estimó que el despido había sido de mala $\mathrm{fe}^{47}$.

También se han limitado los despidos abusivos, que causan angustia, dolor y aflicción al trabajador ${ }^{48}$, como el caso del humillante, o de investigaciones, o interrogatorios abusivos, o por amenazas encubiertas, o por despido violento o agresivo, o con insultos raciales, o por acoso telefónico una vez finalizado el contrato, o agresiones cuando el extrabajador va a la empresa a cobrar lo que se le adeuda ${ }^{49}$.

Las cláusulas tácitas de estabilidad (implied contract), reconocen la existencia de una cláusula de despido por justa causa por voluntad del empleador, por ser un compromiso implícito o verbal, o por derivar de las prácticas o políticas de la compañía ${ }^{50}$. El caso más citado en doctrina es Pugh donde se le despide luego de treinta y dos años de brillante carrera y de leal trabajo para la empresa. Había sido un trabajador clave en el crecimiento y desarrollo de la firma. Se había capacitado numerosas veces para hacer mejor su trabajo. Cuando fue aparatado de sus labores el presidente de la compañía ni siquiera tuvo palabras de agradecimiento por ellas o una razón del despido. Cuando fue contratado el presidente de la época le había asegurado que se trataba de un trabajo seguro y bueno.

\footnotetext{
${ }^{43}$ Mallor (1985), p. 452.

${ }^{44}$ RAY et al. (2011), p. 43.

${ }^{45}$ EdELMAN et al. (1992), p. 52.

${ }^{46}$ Smith, Hodges, Stabile y Gely (2009). p. 39 y n. 117.

${ }^{47}$ Fortune v. NCR, (1977), véase Sмiтh et al. (2009), p. 40.

${ }^{48}$ Agos v. Howard (1976). Véase RaY et al. (2011), pp. 48-49.

${ }^{49}$ RAY et al. (2011), p. 48.

${ }^{50}$ Edelman et al. (1992), p. 52.
} 
La Corte de Apelaciones de California estimó que existía una promesa implícita de estabilidad ${ }^{51}$.

Junto a estas cuatro excepciones y a las normas legales que excepcionalmente limitan el despido ${ }^{52}$, las partes pueden estatuir tanto en el ámbito colectivo como individual ${ }^{53}$ que no regirá el despido libre si no por justa causa ${ }^{54}$. En efecto, todos los contratos colectivos en Estados Unidos estatuyen que el despido debe ser por justa causa y que los conflictos deben ser resueltos por arbitraje. Se ha destacado que este arbitraje suele ser más eficiente y efectivo que las leyes de otros países industrializados ${ }^{55}$. El problema es que beneficia solo a quienes se encuentran cubiertos por contrato colectivo, dejando a la gran mayoría sujeto al despido libre.

En el caso de los contratos individuales, solo en forma excepcional el trabajador logra convencer al empleador de incluir una cláusula de despido por justa causa.

En consecuencia, podríamos resumir los límites al empleo a voluntad de la siguiente forma:

1) Límites legales

2) Límites jurisprudenciales:

2.1 La excepción de orden público

2.2 La excepción de buena fe

2.3 La excepción de despido abusivo

2.4 Las cláusulas tácitas de estabilidad

3) Límites contractuales:

3.1 Contratos colectivos

3.2 Contrato individual

No obstante, la regla general se mantiene y en la casi totalidad de los casos el contrato puede terminar por voluntad de cualesquiera de las partes sin preaviso. Tanto los casos Bammert, Bullard y Nelson son ilustrativos de la vigencia del employment at will en Estados Unidos. En efecto, el despido libre continúa siendo la regla por excelencia y en los juicios por aquellos injustificados por represalia o discriminación prohibida por

${ }^{51}$ Pugh v. See's Candies, (1981), véase RAy et al. (2011), p. 39.

${ }^{52}$ Fundamentalmente la Ley Wagner de 1935 y la Ley de Derechos Civiles de 1964. Véase Summers (1976), pp. 492-493. También los veteranos y los empleados públicos tienen estabilidad en el empleo. Summers (1976), pp. 496-497.

${ }^{53}$ Véase Schwab (1993), p. 8. También existe cierta estabilidad cuando el contrato es a plazo, véase Estreicher y CHerry (2008), p. 56.

${ }^{54}$ Véase Summers (1976), pp. $482-483$ y 499 y ss.

${ }_{55}$ Ibid. Cabe precisar que este "arbitraje colectivo" no es el arbitraje de conflictos individuales que suele imponerse al trabajador en los contratos laborales en Estados Unidos y cuyos resultados distan de ser equitativos. Véase Cohen (2009); Sternlight (2002); Stempel (1991); Hazard y Scott (1988) y Fiss (2007). 
la ley, es el trabajador quien debe acreditar y probar el incumplimiento del empleador, a diferencia de los sistemas laborales comunes, donde es este último quien debe probar la licitud del despido ${ }^{56}$. Es por esto que las dificultades de prueba y los costos de un litigio para el trabajador dificultan el ejercicio de sus derechos, pese a que la ley los proteja ${ }^{57}$.

Por otro lado, se ha destacado cómo los gerentes de recursos humanos y a veces también los abogados corporativos han ayudado a crear pánico respecto de los alcances del despido injustificado. Lo anterior, considerando que no todos los Estados han aceptado las cuatro excepciones (orden público, buena fe, despido abusivo y cláusulas tácitas de estabilidad), y que muchas veces es el empleador quien gana los juicios. En cierta literatura se ha tendido a analizar solo el caso de California (líder en despido injustificado) como si se tratara de legislación federal o como si se hubiera extendido a todos los Estados del país. La verdad es que el impacto del despido injustificado ha sido bastante menor que el que se comenta con alarmismo en las revistas de recursos humanos y de abogados litigante ${ }^{58}$. En efecto, como precisa Cynthia Estlund, el empleo a voluntad sigue operando y limitando los casos de despido injustificado, imponiendo retardos, costos y dificultades probatorias. El poder del empleador, más allá de los límites jurisprudenciales, sigue vigente y ejercido muchas veces abusivamente y en forma invisible ${ }^{59}$.

\section{CRíticAS Al DESPIDO LIBRE O EMPLEO A VOLUNTAD}

El debate sobre la vigencia y amplitud del employment at will ha sido intenso en la doctrina. Clyde Summers lo calificaba en 1976 como un "anacronismo legal" ${ }^{60}$ y otros autores como la "pena capital" del contrato

${ }^{56}$ EstLund (1996), p. 1691.

${ }^{57}$ Ibid.

${ }^{58}$ Edelman et al. (1992), p. 53 y ss. Lauren Edelman, Steven Abraham y Howard Erlanger en este estudio hablan de la "construcción profesional de la ley", a saber, la interpretación y narrativa explicativa que construyen los profesionales acerca de tal o cual ley o decisión jurisdiccional, sobre todo para explicarle a sus clientes los alcances legales respectivos y las probables amenazas. En su investigación contrastaron las revistas de management y de personal, con las legales. Estas últimas, sobre todo las académicas, resultaron ser bastante más imparciales en el tratamiento de los temas laborales. Véase Edelman et al. (1992), pp. 68-74. Aunque puede haber muchas explicaciones para este fenómeno, estos autores resaltan el poder que ganan dentro de las organizaciones estos profesionales y sus relatos amenazantes acerca de las nuevas orientaciones legales, como en el caso de este estudio, el despido injustificado. Op. cit., pp. 74-79.

${ }^{59}$ EstLund (1996), pp. 1657 y 1669 y ss.

${ }^{60}$ Summers (1976), p. 484. 
de trabajo ${ }^{61}$, y en 2016, luego de cuarenta años, este "anacronismo" y esta "pena capital" aún gozan de buena salud ${ }^{62}$.

Un artículo clásico en esta materia es el de Lawrence Blades quien señalaba, a fines de la década de 1960, que era una idea ampliamente aceptada que las grandes empresas podían amenazar la libertad individual en forma comparable a lo que ocurriría si el poder gubernamental no tuviera $\mathrm{control}^{63}$. Esta idea no tiene por qué limitarse a las grandes empresas (a la corporación Mamut), enfatizaba este autor, dado que la libertad se ve amenazada cada vez que un individuo es dependiente de una empresa o entidad privada con mayor poder. $Y$ en este contexto el vínculo más generalizado es el del empleador con el trabajador ${ }^{64}$, donde el primero goza de un "derecho absoluto de despido"65. Lawrence Blades sostenía que los tribunales debían proteger a los trabajadores así como en otras materias habían defendido a las personas de la opresión gubernamental. Para ello, proponía utilizar el Common Law y el Derecho de Daños (Tort Law) para conseguir la tutela frente a los abusos privados de $\operatorname{poder}^{66}$.

También hay defensores del employment at will como Richard Epstein, sobre todo desde la perspectiva del AED y de la necesidad de desregulación ${ }^{67}$.

Richard Posner, por ejemplo, sostiene que la seguridad en el empleo no es eficiente, dado el hecho de que, fuera de los sindicalizados y del sector gubernamental, la forma habitual de contrato es el empleo a volun$\operatorname{tad}^{68}$. Si el empleador gana reputación de despedir arbitrariamente a sus trabajadores, señala, tendrá que pagar una prima a sus empleados nue$\operatorname{vos}^{69}$. Para este autor, todos los problemas se resuelven con el mercado, basado en las negociaciones voluntarias entre las partes ${ }^{70}$. Resulta obvio la inviabilidad de este planteamiento. Casos como Bammert, Bullard o Nelson son de un realismo brutal frente a las afirmaciones de Richard Posner. Volveremos más adelante sobre esta perspectiva del AED.

La consolidación de esta doctrina de libre despido, a principios del siglo xx, está en consonancia con la laissezfaire y con la libertad contractual que imperaba como ideología dominante en el Estados Unidos de esa

\footnotetext{
${ }^{61}$ Young (2001), p. 352.

${ }^{62}$ Arnow-Richman (2016), p. 433.

${ }^{63}$ Blades (1967), p. 1404.

${ }^{64}$ Ibid.

${ }^{65}$ Op. cit., p. 1405.

${ }^{66}$ Op. cit., p. 1435.

${ }^{67}$ Epstein (2011), p. 122 y ss.

${ }^{68}$ Posner (2007), p. 529.

${ }^{69}$ Op. cit., p. 529.

${ }^{70}$ Op. cit., p. 530.
} 
época. Y los profesores de Derecho en general no se habían ocupado de si existía libertad o no para el trabajador en el contrato de trabajo, lo que permite sustentar que fue la libertad de empresa el sustento ideológico del employment at willy no la de contrato ${ }^{71}$. Una excepción en dicha época fue Roscoe Pound, en un popular artículo en que había hecho presente la absoluta falta de libertad negociadora del trabajador, señalando que tal libertad es una falacia persistente ${ }^{72}$ y constatando el surgimiento de "nuevas incapacidades de hecho" derivadas de la nueva situación industrial ${ }^{73}$. Explicaba que las primeras leyes laborales fueron aprobadas cuando el público aún no estaba preparado y, por ello, los tribunales han expresado los temores del viejo orden frente al nuevo, reforzando una libertad contractual inexistente en materia laboral ${ }^{74}$.

Katherine Stone ha señalado contraintuitivamente que el despido libre tuvo algunos efectos positivos, a principios del siglo xx, para los obreros no especializados. Estos trabajadores estaban sujetos a la doctrina del contrato completo (entire contact doctrine), que exigía la total ejecución del mismo para tener derecho al pago, a la remuneración. De forma que si el obrero renunciaba o era despedido no podía recibir la paga por el trabajo realizado parcialmente hasta ese momento. Esta situación cambia con el employment at will y permite al trabajador recibir la paga por las labores efectivamente realizadas hasta el término del contrato ${ }^{75}$. Claro que estas no fueron buenas noticias para los trabajadores especializados. La nueva movilidad de los obreros sin calificaciones permitió reemplazarlos fácilmente para integrarlos a los sistemas productivos desarrollado por Frederick Taylor que requería personal de baja calificación. Además, según Katherine Stone, el empleo a voluntad favoreció la contratación estándar en Estados Unidos, de tiempo indefinido, donde el empleador se ganaba la lealtad del trabajador asegurándole estabilidad en su puesto ${ }^{76}$.

${ }^{71}$ Shapiro y Tune (1974), p. 343. Clyde Summers enfatiza, además, que en afinidad con el laissez faire sería postular una interpretación neutral de la intención de las partes y no una presunción en favor del empleador. Véase Summers (2000), p. 68.

${ }^{72}$ Pound (1908-1909), p. 454.

${ }^{73}$ Op. cit., p. 468.

${ }^{74}$ Op. cit., pp. 457-458. Roscoe Pound critica tanto a los tribunales federales como estatales que declararon inconstitucionales numerosas leyes protectoras del trabajador en la conocida "Era Lochner" (Véase GAMONAL y RosAdo (2014a), p. 30 y ss.), señalando que la gran mayoría de estas decisiones son erróneas desde la perspectiva constitucional, del Common Lawy, aun, desde una filosofía individualista cuerda. Una tal libertad contractual irrestricta ha sido inexistente en el Common Law, manifiesta Roscoe Pound, dado que los tribunales por medio de la equidad siempre han intervenido en favor del contratante débil, necesitado o desafortunado. Véase Pound (1908-1909), p. 482.

${ }^{75}$ Stone (2013), p. 62.

${ }^{76}$ Op. cit., p. 62. 
Se ha enfatizado que el despido libre implica asumir que el empleador tiene el poder para dictar las reglas, interpretarlas unilateralmente, disciplinar su cumplimiento y despedir en forma arbitraria, sin que sea relevante la voluntad real de ambas partes, en este caso del trabajador ${ }^{77}$. Se ha sostenido que el empleo a voluntad se impuso y logró su éxito porque permitió el desarrollo del capitalismo avanzado en Estados Unidos, reforzando la subordinación de los trabajadores no calificados y de los mandos medios, siendo una suerte de garantía de la autoridad del dueño del capital sobre ellos ${ }^{78}$. Asimismo, el despido libre permitió disminuir estos costos, facilitando el término de contrato en las crisis económicas ${ }^{79}$.

El empleo a voluntad, en la visión de los tribunales de principios del siglo $\mathrm{xx}$, favorece el crecimiento económico y el espíritu empresarial, aunque conlleva una virtual abdicación de supervisar legalmente el poder del empleador. Casos como Adair v. United States marcan la pauta de una Corte Suprema Federal tributaria del laissezfaire, apesar de una importante preocupación de los legisladores, dado que la libertad de contratación en materia laboral no era más que una cruel ilusión debido a las grandes diferencia negociadora entre las partes ${ }^{80}$.

Raymond Hogler explica que al año siguiente del libro de Stephen Wood, en 1878, Frederick Winslow Taylor introdujo la técnica del scientific management ${ }^{81}$, el cual fue resistido por los trabajadores calificados, aunque finalmente logró imponerse ${ }^{82}$. En este contexto, el despido libre ayudó a consolidar el poder de control del empleador en el lugar de trabajo y el proceso productivo, así como la expansión de la homogeneización del trabajo de baja calificación postulada por Frederick Taylor ${ }^{83}$. El Derecho de Contratos y el employment at will permitieron que estos cambios radicales en la forma de producción (del trabajo calificado al semicalificado otorgando el control absoluto de este proceso al empleador) pareciera como voluntariamente aceptado por los trabajadores, legitimando de esta forma al nuevo orden ${ }^{84}$. En palabras de Frederick Taylor el scientific management implicaba una "revolución mental completa" ${ }^{85}$. Los trabajadores

77 Atleson (1997), p. 443.

${ }^{78}$ Feinman (1976), pp. 131-133.

${ }^{79}$ Op. cit., p. 134.

${ }^{80}$ Harvard Law Review (1980), p. 1826.

${ }^{81}$ Basado en la producción en cadena (trabajo homogeneizado) con labores muy específicas hechas por trabajadores no especialistas o semicalificados. Véase HogLer (1985), p. $30 \mathrm{y}$ ss.

${ }^{82}$ Hogler (1985), p. 27.

${ }^{83}$ Op. cit., p. 28 y n. 10.

${ }^{84}$ Op. cit., n. 11.

${ }^{85}$ Citado por Hogler (1985), p. 34. 
se resistieron a estos cambios, pero esta nueva forma de producción se impuso por la fuerza y resultó triunfante gracias a un instrumento legal clave: el despido libre o empleo a voluntad ${ }^{86}$.

Analizando los escritos de Frederick Taylor y los argumentos de los tribunales en el employment at will, Raymond Hogler pone en evidencia su gran paralelismo sobre la base de la ideología de la libertad y del consentimiento $^{87}$. Según Frederick Taylor el scientific management sería un sistema basado en la objetividad, la generalidad y la autonomía, y cada parte se mantendría libre de la dominación de la otra, actuando en favor de sí misma. Este sistema, según lo concibe su creador, replicaría la estructura del Estado de derecho en la sociedad moderna, sobre la base de procedimientos formales en vez de equidad sustantiva, dependiendo su legitimidad de su neutralidad y de su contenido basado en valores libres ${ }^{88}$. Esta simbiosis entre el scientific management y el employment at will, según Raymond Hogler, se presenta también en el declive de ambas construcciones, dado que la doctrina del despido injusto es paralela a la erosión del scientific management como proyecto industrial ${ }^{89}$.

Por otro lado, como las trabajadoras y las personas de color son, proporcionalmente, despedidas en mucho mayor porcentaje que los hombres blancos, se ha dicho que el despido libre facilita la discriminación y subordinación de estas personas en el trabajo ${ }^{90}$.

Desde una perspectiva racial, no deja de ser sospechoso que la regla americana surgiera pocos años después de la Guerra Civil y de la libertad de los negros. En otras palabras, los esclavos pasaron a ser trabajadores, y resulta a lo menos extraño que la regla inglesa no engendrara problemas ni debates cuando era aplicada solo a los blancos. En este punto resultan pertinentes las irónicas palabras que nos recuerda Donna Young del presidente Andrew Johnson (1865 a 1869), durante el periodo de reconstrucción luego de la Guerra Civil:

"No es tan mala la condición de liberto. Su trabajo es demandado y puede cambiar su lugar de residencia si una comunidad o el estado no le agradan. Las leyes de la oferta y la demanda regularán sus salarios. Los libertos pueden protegerse a sí mismos y ser libres, y

${ }^{86}$ Hogler (1985), p. 28 y n. 36.

${ }^{87}$ Op. cit., p. 44.

${ }^{88}$ Op. cit., p. 45.

${ }^{89}$ Op. cit., pp. 46 y 53-58. El declive del proyecto de Frederick Taylor se produce por el surgimiento de sistemas flexibles de producción y técnicas más persuasivas de control del trabador. Op. cit., pp. 50-53.

${ }^{90}$ Young (2001), p. 355 y ss. 
auto mantenerse, siendo capaces de seleccionar su propio empleo requiriendo a la vez los salarios pertinentes" ${ }^{\prime 1}$.

Es claro que los libertos que habían sido esclavos toda su vida difícilmente operarán en el mercado libre, considerando las secuelas de la esclavitud y su falta de educación ${ }^{92}$. Pasados más de ciento cincuenta años desde el término de la Guerra Civil, la perseverancia del empleo a voluntad refleja el interés de que las personas de color y las mujeres continúen subordinados por esta doctrina formalista de igualdad, perpetuando una inequidad substantiva ${ }^{93}$.

Además, la vigencia del empleo a voluntad ha erosionado la tutela de los derechos civiles dentro del contrato de trabajo. Como ha enfatizado Ann McGinley, por ejemplo, en el caso St. Mary's Honor Center v. Hicks ${ }^{94}$, la Corte Suprema Federal recuerda que la regla general sigue siendo el despido libre, aunque haya leyes protectoras de los derechos civiles. El señor Melvin Hicks demandaba despido por razones de raza presentando indicios razonables en este sentido. El empleador, por su parte, presentó prueba de que su actuar se debía a que Melvin Hicks no cumplía las reglas a las que estaba sometido en el lugar de trabajo. Los tribunales concluyeron que esto era solo un pretexto del empleador, dado que otros compañeros habían vulnerado en peor forma las reglas y no habían sido despedidos. Sin embargo, la Corte Suprema Federal revirtió esta decisión por estimar que, pese a que se había probado que se trataba de un pretexto del empleador, el demandante debería ir ante un jurado para acreditar la efectividad de la discriminación. Como la no discriminación es una excepción al empleo a voluntad, se la interpreta restrictivamente en esta sentencia frente al despido libre. En otras palabras, aun cuando el despido sea injusto no por ello es discriminatorio ${ }^{95}$.

Comentado otro caso, sobre discriminación por edad, Ann McGinley critica el voto del juez y profesor Richard Posner y lo señala como ejemplo del predominio del empleo a voluntad. Se trata del caso Visser ${ }^{96}$ donde un trabajador de sesenta y cuatro años fue despedido nueve meses antes de tener derecho a jubilar, disminuyéndose el monto final de su jubilación. Aunque se acreditó que el despido se basó en que el trabajador se había negado a jurarle lealtad al señor Packer, gerente general y fundador de la compañía, quien había estado robando en la empresa (la lealtad del

\footnotetext{
${ }^{91}$ Young (2001), p. 367.

${ }^{92}$ Op. cit., p. 368.

${ }^{93}$ Op. cit., p. 374.

${ }^{94}$ St. Mary's Honor Center v. Hicks (1993).

${ }^{95}$ McGinley (1996), pp. 1457-1459.

${ }^{96}$ Visser v. Packer (1991).
} 
trabajador estaba en la empresa), Richard Posner estimó que no había pruebas de que se le hubiera despedido para perjudicarlo en su jubilación ${ }^{97}$. Como señala Ann McGinley, la relación empleador-trabajador es tan compleja que normalmente es una serie de acontecimientos entrelazados, experiencias y motivaciones las que conducen a la decisión de despedir a un empleado. Por tanto, es imposible que el trabajador pueda separar estas motivaciones en su demanda, sobre todo porque la doctrina del empleo a voluntad que subyace puede basarse en motivos distintos a los prohibidos por la ley ${ }^{98}$.

Se ha sugerido, desde otro punto de vista, que el employment at will no puede ser estimado parte del Derecho Laboral, por carecer de la vocación protectora del Derecho del Trabajo ${ }^{99}$. Como señala Paul Weiler, el empleo a voluntad se enmarca dentro del contexto del Derecho Contractual, donde en teoría las partes son perfectamente libres de alterar esta regla ${ }^{100}$.

La doctrina laboralista estadounidense ha insistido en la necesidad de adoptar una legislación federal de despido, contemplando un sistema por justa causa ${ }^{101}$. Asimismo, se ha propuesto que deben considerarse todos los cambios que han operado en el capitalismo desde fines de 1800 hasta nuestros días, lo que exige reexaminarla ${ }^{102}$. Por ejemplo, la estabilidad en el empleo no parecía necesaria mientras había crecimiento y predominaba la ideología liberal en Estados Unidos, sin embargo, considerando la cantidad de abusos que permite el employment at will, Steward Macaulay señala la necesidad legislar al respecto ${ }^{103}$.

Por otro lado, más de la mitad de los trabajadores de Estados Unidos no sabe que está sujeto al empleo a voluntad y cree firmemente que solo puede ser despedido por justa causa ${ }^{104}$. Asimismo, se ha enfatizado acerca de

${ }^{97}$ McGinley (1996), pp. 1459-1461.

${ }^{98}$ Op. cit., p. 1461.

${ }^{99}$ Gamonal y Rosado (2014b), p 659 y Gamonal y Rosado (2014a), p. 103.

${ }^{100}$ Weiler (1993), p. 48.

${ }^{101}$ Summers (1976), p. 481, quien sugiere un sistema de arbitraje colectivo como el pactado por los sindicatos; Young (2001), pp. 355 y 406 y ss., quien sugiere seguir el sistema de preaviso de Canadá, y Arnow-Richman (2010), p. 49 y ss., quien también defiende un sistema de término con preaviso como el de Canadá, comentando, además, los casos de Gran Bretaña, Alemania y Puerto Rico.

102 Feinman (1991), p. 740.

${ }^{103}$ Macaulay (1985), p. 435. Este autor enfatiza que los eventuales beneficiarios de una ley de estabilidad en el empleo carecían, en la década de 1980, del poder suficiente para promover una iniciativa legislativa en este sentido. Esta falta de presencia política de los trabajadores se mantiene hasta nuestros días e, incluso, se ha agravado. Véase Hacker y Pierson (2011).

${ }^{104}$ Estlund (2002), pp. 7-8. 
los efectos financieros devastadores que tiene el despido libre ${ }^{105}$, así como otras indeseables consecuencias en el ámbito social y de salud mental ${ }^{106}$. En 1991 la National Conference of Commissioners on Uniform State Laws propuso un proyecto modelo de término de contrato para Estados Unidos, denominado META. El proyecto proponía un sistema de arbitraje barato y rápido, estableciendo un sistema de justa causa y limitando la responsabilidad del empleador al igual que la ley de Montana. Pese a que fue presentado como proyecto en numerosos Estados, ninguno aprobó leyes en este sentido ${ }^{107}$.

\section{El empleo a voluntad y el Derecho del Trabajo}

Desde la perspectiva del Derecho Laboral latinoamericano resulta obvio que el empleo a voluntad es inadmisible. La doctrina de nuestros países está conteste en la vocación protectora del Derecho Laboral ${ }^{108}$.

Por ello, nos centraremos en la visión anglosajona del Derecho del Trabajo, para demostrar que, en coincidencia con los autores de Latinoamérica, el despido libre afecta la esencia del Derecho del Trabajo. Para este cometido, evaluaremos el employment at will desde la óptica de la doctrina laboral estadounidense, desde el AED e, incluso, desde una perspectiva ética.

\section{La doctrina laboral estadounidense}

Respecto de la doctrina laboralista de Estados Unidos, se examinarán los argumentos disidentes del juez Oliver Wendell Holmes Jr. a principios del siglo Xx, y algunos planteamientos de los profesores de Derecho ${ }^{109}$.

${ }^{105}$ McGinley (1996), p. 1496.

${ }^{106}$ Problemas como muertes cardiovasculares, suicidios, crisis nerviosas, alcoholismo, violencia intrafamiliar y abuso, así como deterioro social. Véase ST. Antorne (1992), p. 496.

${ }^{107}$ Op. cit., pp. 495-500. Más recientemente, el American Law Institute ha propuesto en 2008 el denominado Restatement of the Law for Employment Law. Esta propuesta a diferencia del estatuto de Montana o del META solo busca ordenar y clarificar el Derecho existente. Véase Sмiтh et al. (2009), p. 69.

${ }^{108}$ Véase, por ejemplo: Plá (1998), p. 61; Barbagelata (2009), p. 20; Ermida (2011), p. 8; Ackerman (2005), pp. 317-312; Macchiavello (1986), pp. 23 y 53 y Gamonal (1998), pp. 12 y 132 .

${ }^{109}$ La literatura acerca de los fines y del futuro del Derecho Laboral es muy extensa en inglés. A modo ejemplar podemos mencionar: Compa (2014); DAvidov y LANGiLle (2011); Tucker (2010); Davies (2009); Befort y Budd (2009); Atleson (1997); Deakin y Wilkinson (1994); Coluins (1989); Summers (1988); Sunstein (1984); Fried (1984); Posner (1984); Klare (1981); Kennedy (1981), y Klare (1978). 
Este juez de la Corte Suprema Federal es conocido por haber sido uno de los fundadores del realismo jurídico estadounidense, pero también es famoso por sus votos disidentes en materia laboral. Probablemente la más famosa de sus disidencias sea el caso Lochner ${ }^{110}$. Sin embargo, tuvo varias otras disidencias laborales y en otros temas y, como señalaba Felix Frankfurter, no tuvo problemas en considerar constitucional la legislación que buscaba la paz social y la promoción de estándares sociales civilizados en el comercio interestatal ${ }^{111}$, aun yendo en contra de la opinión mayoritaria de la Corte Suprema Federal ${ }^{112}$.

Como señalábamos al inicio de este artículo, en el caso Adair v. United States, de $1908^{113}$, la Corte Suprema Federal ratificó la regla del despido libre, al estimarse inconstitucional la ley Erdman de 1898, que prohibía a las empresas de transporte de ferrocarriles despedir a un trabajador por causas de su afiliación sindical. El voto disidente de Oliver Holmes, recordando lo dicho en el caso Lochner, hizo presente que el legislador puede perfectamente limitar la libertad contractual sobre la base de las políticas públicas ${ }^{14}$. En efecto, su voto disidente en Lochner, por considerar adecuada una legislación de Nueva York, que establecía límites a la jornada de trabajo en panaderías, es bastante conocido y citado. El juez impugnaba que la mayoría de la Corte Suprema interpretara la Constitución desde una perspectiva económica:

"Una Constitución no está destinada a incorporar una teoría económica en particular, ya sea la teoría del paternalismo o la de la relación orgánica de los ciudadanos en el Estado o la del laissezfaire. Está hecha para un pueblo de opiniones fundamentalmente diferentes" ${ }^{\prime 15}$.

En otro caso famoso, Coppage v. Kansas, el Estado de Kansas había dictado una ley en 1903 prohibiendo el contrato de perro amarillo (yellow dog) en cuya virtud se condiciona el empleo del trabajador a que no se afiliara a un sindicato. En este caso, del año 1915, la Corte Suprema federal declaró la inconstitucionalidad de dicha ley por limitar la libertad sin un debido proceso. Oliver Holmes fue disidente señalando:

${ }^{110}$ Gamonal y Rosado (2014a), pp. 31-32.

${ }^{111}$ Como la Constitución de Estados Unidos no contempla derechos laborales, el gobierno se amparaba en la facultad de regular el comercio interestatal, pero la Corte consideró excesivo este planteamiento.

${ }^{112}$ Frankfurter (1927), p. 136.

${ }^{113}$ Steidle (1999), p. 5.

${ }_{114}$ Op. cit., p. 5.

${ }^{115}$ LAmbert (2010), n. 60, p. 75 (subrayados en el original). 
"En las condiciones actuales, un trabajador puede no antinaturalmente creer que sólo por la pertenencia a un sindicato puede asegurarse un contrato que sea justo para él" ${ }^{116}$,

agregando:

"Si esa creencia, tanto acertada como errónea, puede mantenerse por un hombre razonable, me parece a mí que puede ampararse por el Derecho, con la finalidad de establecer la igualdad de posición entre las partes, con la que empieza la libertad de contratación" 117 .

Como comenta Erwin Chemerinsky, la mayoría de la Corte estaba decididamente del lado de los negocios, impidiendo a las legislaturas proteger a los trabajadores que deseaban sindicalizarse ${ }^{118}$.

Oliver Holmes es autor, además, de otra de las disidencias más famosas de la Corte en el caso Hammert, en 1918, en materia de prohibición de trabajo infantil, señalando que un punto de acuerdo en todas las naciones civilizadas era lo pernicioso del trabajo infantil prematuro y excesivo ${ }^{119}$. En 1916 se había aprobado una ley federal que prohibía el trabajo infantil (Keating-Owen Chiled Labor Act), y en este caso fue declarada inconstitucional por la mayoría de la Corte, estimando que afectaba los poderes de cada Estado y los equilibrios del federalismo ${ }^{120}$. Luego, el Congreso intentó prohibir nuevamente el trabajo infantil sobre la base de su facultad de establecer tributos, pero volvió a ser declarada inconstitucional. Por último, en 1941, la unanimidad de la Corte declararía la constitucionalidad de la Fair Labor Standard Act, que estableció en 1938 una serie de derechos laborales mínimos en el ámbito federal, adoptando las tesis de Oliver Holmes. Por ello, en esa ocasión el juez Harlan Fiske Stone diría que las disidencias de Oliver Holmes (quien se había retirado en 1932 y fallecido en 1935 a los noventa y cuatro años) eran poderosas y aún clásicas ${ }^{121}$.

Oliver Wendell Holmes Jr. es el juez más famoso en la historia de la Corte Suprema de Estados Unidos y debiera ser conocido, además, como uno de los primeros laboralistas estadounidenses, quien no dudó en ser minoría durante años con tal de defender los estándares civilizatorios del

${ }^{116}$ Arufe (2009), p. 15.

117 Op. cit., p. 15.

${ }^{118}$ Chemerinsky (2014), p. 98.

${ }^{119}$ Voto disidente en el caso Hammer v. Dagenhart, (1918). Citado por Frankfurter (1927), p. 137.

${ }^{120}$ Wood (1999), pp. 122-123.

${ }^{121}$ United State v. Darby Lumber (1941). Véase Wood (1999), p. 123. 
Derecho del Trabajo. Entre estos estándares estaba la idea de limitar el empleo a voluntad, ideal aún pendiente en el siglo XXI.

Desde una óptica doctrinaria y más global, para Guy Davidov uno de los objetivos tradicionales del Derecho Laboral es la protección del trabajador ${ }^{122}$. Esta articulación se basa en la noción de poder desigual, pero también se fundamenta en el carácter redistributivo como un objetivo importante, así como en las vulnerabilidades, los déficits democráticos y la dependencia del trabajador ${ }^{123}$. La desigualdad de poder se expresa tanto al negociar el contrato como al tener que ejecutar en forma subordinada la prestación de servicios ${ }^{124}$. Mientras el empleador se compromete al pago de una remuneración, el trabajador se obliga a prestar servicios y a someterse a su poder, en virtud de cláusulas abiertas e indeterminadas. En este punto es evidente lo inequitativo del contrato de trabajo ${ }^{125}$. Como el poder desigual es inherente a esta convención, se hace necesario regularlo para prevenir abusos de poder del empleador ${ }^{126}$.

Como vemos, en el planteamiento de Guy Davidov, no hay novedades relevantes al compararlo con la doctrina de América Latina, el trabajador es el débil de la relación con su empleador y debe ser resguardado por el Derecho del Trabajo.

Por otro lado, Cass Sunstein destaca las falencias de mercado (sobre todo las asimetrías de información), las metas redistributivas y los fines paternalistas como razones que pueden sustentar una teoría del Derecho del Trabajo 127 . Según sus mismas palabras: "las consecuencias de tratar al trabajador como mercancía pueden ser muy dramáticas" ${ }^{128}$. El mercado de trabajo tiene características especiales, dado que el trabajador pasa gran parte de su vida adulta en el lugar de empleo, y la estructura del lugar de trabajo crea relaciones que dominan parte importante de su vida ${ }^{129}$.

La presunción en contra de la intervención gubernamental en los contratos opera siempre ex ante, según Cass Sunstein, o sea, en el contexto del mercado libre y de que cada parte debe negociar de manera voluntaria sus acuerdos, deben ser evaluados impersonalmente para que opere la oferta y la demanda. Si el contrato resulta en una desventaja para uno de los contratantes, este no puede eximirse de dar cumplimiento a la palabra empeñada ${ }^{130}$.

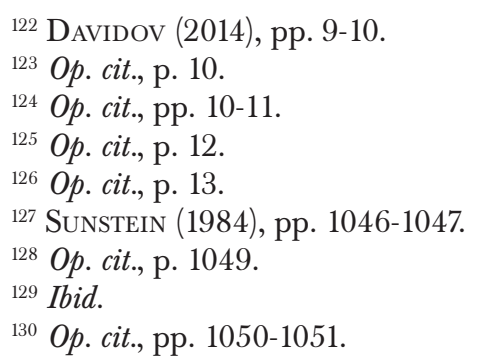


Sin embargo, si se examina el empleo a voluntad, por ejemplo, defendido en un contexto ex ante como un acuerdo que siempre beneficiará a ambas partes, este argumento resulta dudoso porque no siempre los contratos de trabajo favorecen a ambas partes. Existen asimetrías de información, como que el trabajador cree que no puede ser despedido por capricho o, sabiéndolo, no evalúa bien los riesgos y cree que nunca lo van a despedir. Por tanto, puede haber argumentos de eficiencia (asimetrías de información) y paternalistas (no cree que lo vayan a despedir), que justifiquen la introducción por ley de justa causa como mínimo irrenunciable para terminar el contrato de trabajo ${ }^{131}$. Cass Sunstein sostiene que una teoría del derecho del trabajo debe fundarse consistentemente en este tipo de consideraciones ${ }^{132}$.

En consecuencia, una doctrina tan particular y excepcional (solo de Estados Unidos) como el empleo a voluntad erosiona la idea protectora del Derecho del Trabajo y, por ello, no resulta descabellado enfatizar que el employment at will no es Derecho Laboral ${ }^{133}$.

Por más que se plantee que esta doctrina del despido libre es tributaria del Derecho de Contratos y de la libertad contractual ${ }^{134}$, desde la perspectiva del Derecho Privado tampoco se sostiene este privilegio del empleador. Roscoe Pound hacía presente a principios del siglo Xx que, incluso desde la perspectiva del Common Law, el contratante débil merece tutela ${ }^{135}$. Mucho más adelante, en el último cuarto del mismo siglo, Charles Fried reconoce que en el mercado de la vivienda, del consumo o del transporte, cuando hay falencias de mercado o razones paternalistas o distributivas, o el resultado de la libertad contractual se cree intolerable, la intervención del gobierno se dirige en forma directa en favor del más débil ${ }^{136}$.

Michael Zimmer ha enfatizado, por otra parte, que el riesgo diario de perder el trabajo, gracias a la doctrina del empleo a voluntad, afecta al seguridad del trabajador porque tanto el plan de salud como su eventual futura pensión dependen de este estatus ${ }^{137}$, por tanto, el riesgo de perder el empleo no solo afecta su subsistencia inmediata sino, también, todo el ámbito de su seguridad.

${ }^{131}$ Sunstein (1984), pp. 1052-1056.

${ }^{132}$ Op. cit., p. 1057.

${ }^{133}$ Gamonal y Rosado (2014b), p 659 y Gamonal y Rosado (2014a), p. 103.

${ }^{134}$ WeILer (1993), p. 48. Debemos precisar que Paul Weiler es muy crítico del empleo a voluntad.

${ }^{135}$ Pound (1908-1909), p. 482.

${ }^{136}$ Fried (1984), p. 1019. En este trabajo Charles Fried está más a favor del derecho individual del trabajo que del colectivo. Cass Sunstein lo critica fuertemente en el artículo suyo que hemos citado en la n. 127 supra.

${ }^{137}$ Zimmer (2013), p. 24. 
Como indicábamos en su momento, Clyde Summers señalaba en 1976 que el employment at will es un "anacronismo" del sistema estadouniden$\mathrm{se}^{138}$, y que el poder de las grandes empresas es de tal magnitud que se les deberían aplicar las mismas limitaciones constitucionales que rigen para el Estado, en especial la enmienda XIV sobre debido proceso ${ }^{139}$. Todos los trabajadores deberían estar tutelados por el debido proceso ${ }^{140}$. Clyde Summers solicitaba la dictación de una ley federal que regule el despido con estándares objetivos ${ }^{141}$. Concluía enfatizando que no debería ser necesario ningún argumento para demostrar que deben estar protegidos en contra del despido arbitrario o injusto. Para muchos, su posesión más preciada es su trabajo, por tanto, no resulta descabellado decir que tienen un derecho de propiedad sobre los mismos. Al igual que los sindicatos han brindado esta protección por vía de los contratos colectivos, el Estado debiera otorgarla por ley a todos los empleados de Estados Unidos ${ }^{142}$. Años más tarde, Clyde Summers insistiría en contra del empleo a voluntad, denominándolo como un "derecho divino del empleador" y una suerte de "sistema monárquico" 143 , enfatizando que esta doctrina permite el control y subordinación del trabajador, porque él puede cambiar en cualquier momento los términos y condiciones de empleo y puede despedir sin causa y sin previo aviso ${ }^{144}$.

Finalizaremos esta parte, relativa a la doctrina laboral, recordando las palabras de Archibald Cox quien, a fines de la década de 1950, decía que producto de la Revolución industrial Estados Unidos se había transformado desde una nación de agricultores y artesanos independientes a una de asalariados, dependientes de su salario diario para sobrevivir, y que difícilmente podían negociar con las empresas el precio de su trabajo. Agregaba que la seguridad en el empleo se había vuelto un tema relevante, dado que el trabajo era la única fuente de sobrevivencia y de perfeccionamiento. Por otro lado, añadía, la reunión de miles de obreros dentro de la fábrica permitía un gran poder concentrado en unas pocas manos (los gerentes), pudiendo ejercerse de manera fácil con arbitrariedad. Por ello, los hombres habían perdido el orgullo y las habilidades que los caracterizaban como antiguos artesanos y se veían a sí mismos como meras unidades de trabajo ${ }^{145}$.

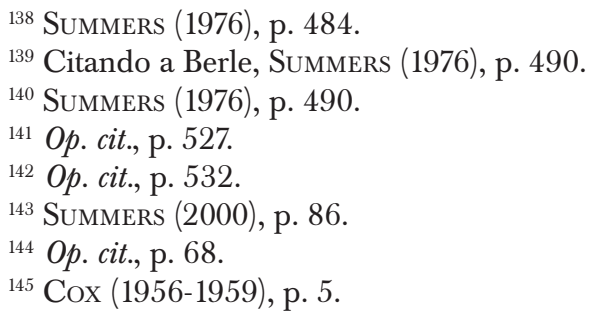


Más de cincuenta años después estas palabras mantienen vigencia en Estados Unidos.

\section{2. $E l A E D$}

Desde una perspectiva de AED, los argumentos son bastante claros en contra del Derecho Laboral y a favor del empleo a voluntad. Richard Posner entiende que la falta de acuerdos individuales entre trabajador y empleador, para consagrar un sistema de justa causa, demuestra que esta no sería eficiente, en otras palabras, el mercado ha dado su veredicto en Estados Unidos y, por ello, la mayoría de los trabajadores siguen sometidos al empleo a voluntad, porque no lo negocian y esto es así porque no lo desean como beneficio ${ }^{146}$.

En el mismo sentido opina Richard Epstein, quien señala que la sobrevivencia del empleo a voluntad y la frecuencia de su uso puede considerarse un signo de su idoneidad ${ }^{147}$. Para este autor la doctrina del despido injustificado es el problema y no la solución ${ }^{148}$.

Asimismo, indica que debe respetarse la libertad de las partes, si se desea que el empleo sea a voluntad, porque la libertad contractual permite la concreción de la autonomía individual y ayuda a que los mercados

76 de trabajo sean eficientes ${ }^{149}$. Ante el silencio de las partes, indica, debe elegirse la regla que dé mayor previsibilidad y que opere en favor de ambos contratantes, a saber, el employment at will que, además, refleja la práctica dominante en el mercado ${ }^{150}$. Introducir por ley un sistema de justa causa altera este equilibrio ${ }^{151}$. Si la regulación estatal de la vida personal, de la vida religiosa o de las actividades políticas es indeseable, ¿ por qué va a ser deseable esa intervención en las relaciones laborales?, pregunta Richard Epstein ${ }^{152}$.

El empleo a voluntad opera en favor de ambas partes y los derechos en este caso son bilaterales, es decir, el trabajador puede ocupar sus derechos como un medio para controlar a la compañía y la compañía puede ocupar sus derechos para controlar al trabajador ${ }^{153}$. Definitivamente, para este autor, el empleo a voluntad es muy eficiente sobre todo por los bajos costos tanto del despido como de la renuncia, lo que lo haría tan común

\footnotetext{
${ }^{146}$ Posner (2007), p. 529.

${ }^{147}$ Epstein (1984), p. 948.

148 Op. cit., p. 982.

${ }^{149}$ Op. cit., p. 951.

${ }^{150}$ Ibid.

${ }^{151}$ Op. cit., p. 952.

${ }^{152}$ Op. cit., p. 954.

${ }_{153}$ Op. cit., p. 957.
} 
y popular en Estados Unidos ${ }^{154}$. Y este sistema, según el mismo autor, evita los abusos del empleador porque el trabajador puede renunciar por una buena razón, sin razón o, también, por una mala razón ${ }^{155}$. Además, el empleo a voluntad es muy barato de administrar, a diferencia de un sistema de justa causa que generará numerosos litigios y para los trabajadores es más fácil superar los errores de un despido, porque rápidamente puede conseguir un nuevo empleo o facilitándole esta tarea, porque no implica un incumplimiento o falta del trabajador, dado que todos los contratos de trabajo son a voluntad ${ }^{156}$.

Por otro lado, Richard Posner opina que si un empleador es arbitrario o caprichoso nadie querrá contratarse con él, en buenas cuentas el mercado lo castigará y deberá enmendar su conducta o pagar más ${ }^{157}$. La clave del sistema es el mercado: donde las partes negocian en forma voluntaria los contratos $^{158}$.

Todos estos argumentos no se sustentan en la evidencia empírica. Por cada hipótesis que da Richard Posner o Richard Epstein podemos encontrar numerosos casos en un sentido diametralmente opuesto. Es posible decir, por ejemplo, que la falta de acuerdos individuales sobre justa causa demuestra la debilidad negociadora de los trabajadores. Por ello, cuando se sindicalizan, lo primero que hacen es establecer en el ámbito colectivo el despido por justa causa.

Para Richard Posner los trabajadores no se contratarán con empleadores caprichosos o arbitrarios. Pero en la realidad ocurre al revés, el trabajador jamás sabe cómo es el empleador (por las asimetrías de información), quien presenta un curriculum vitae es el trabajador, y es un hecho que muchos se emplean con jefes que en el pasado han sido acosadores y, por tanto, hay dos alternativas: o nunca lo supieron o no les incomoda el acoso sexual. Richard Epstein señala que el trabajador puede renunciar por buena, mala o ninguna causa. Pero esta aseveración resulta bastante alejada de la realidad diaria. Si renunciar no tuviera costos familiares y de sustento de vida, no sería necesario prohibir el acoso o establecer por ley condiciones de higiene y seguridad, mal que mal siempre el trabajador podría renunciar...

Resulta evidente que el mercado de trabajo es sumamente imperfecto y, por ello, es difícil que este tipo de argumentos del AED puede afectar al Derecho del Trabajo y erosionar la necesidad de tutela del trabajador.

\footnotetext{
${ }^{154}$ EPSTEIN (1984), p. 965.

${ }^{155}$ Op. cit., p. 966.

${ }^{156}$ Op. cit., p. 970.

${ }^{157}$ Posner (2007), p. 529.

${ }^{158}$ Op. cit., p. 530.
} 
La escuela del AED subordina el Derecho a los imperativos del mercado $^{159} \mathrm{y}$, además, se basa en la economía como si fuera una ciencia exacta ${ }^{160}$. Lo primero es muy discutible, porque el Derecho se fundamenta en un sistema de valores superiores a un análisis pragmático de costo beneficio. Los derechos fundamentales son un ejemplo de ello y los derechos laborales están presentes en todos los catálogos de derechos humanos. Como señala Alain Supiot, un derecho fundado solo en el cálculo de utilidades individuales es preocupante:

"porque un mundo donde cada uno no se vea obligado por sus compromisos sino en la medida en que le convenga es un mundo donde la palabra ya no vale nada" 161 .

Lo segundo, esto es, la pretensión de la economía de ser una ciencia exacta de tipo matemático es una falacia. La economía es una ciencia social, se basa en la conducta del ser humano, la que es muchísimo más compleja que el análisis simplista que se propone con el "hombre económico" ultrarracionalista ${ }^{162}$. Por tanto, muchos de los consejos económicos son pseudocientíficos (refiriéndonos a las ciencias exactas), aparentemente técnicos, pero en realidad, ideológicos, tan discutibles o inexactos como los del Derecho u otras ciencias sociales. En el caso del neoliberalismo esto es claro. Los consejos de los expertos de esta tendencia, en nombre del crecimiento, han sido mediocres en sus resultados ${ }^{163}$. Y el único logro visible es una redistribución de la riqueza desde los pobres a los ricos ${ }^{164}$.

${ }^{159}$ Como dice José Luis Ugarte el análisis económico del Derecho “coloca al derecho laboral de rodillas", UGARTE (2001), p. 32.

${ }^{160}$ Autores como Guido Calabresi son más moderados dentro del AED. Este autor señala que su línea de trabajo es más bien de Derecho y Economía, dado que el AED consiste en aplicar teorías económicas para analizar, criticar o confirmar teorías legales vigentes, tomando la economía como dada, a diferencia de la corriente de Derecho y Economía que toma como punto de partida el Derecho, mira el mundo real del Derecho y se pregunta si la economía puede explicarlo. Cuando la teoría económica no puede dar una respuesta, en vez de asumir que el mundo real está mal o es irracional, el abogado de Derecho y Economía se pregunta si esa teoría económica puede alterarse o expandirse para explicar mejor la realidad legal. Véase CALABResi (2011), pp. 13-14.

${ }^{161}$ SupIOT (2007), p. 166.

${ }^{162}$ La literatura es amplia respecto de los limitados puntos de vista de la economía dogmática supuestamente científica. Por ejemplo: Colander (2001); Fourcade, Ollion y Algan (2015); Mayer (2006); O’neill (2013) y Sen (2011).

${ }^{163}$ Chang (2012), pp. 78-86 y 88-98.

${ }^{164}$ HaRvey (2007). La redistribución de pobres a ricos es bastante visible en relación con las diferencias salariales entre los gerentes o managers y trabajadores. Michael Sandel destaca que en 1980 la remuneración promedio de los directores generales en Estados Unidos, respecto del trabajador promedio, era cuarenta y dos veces mayor. En 2007 era de 
Parte de esta redistribución inversa ha sido el intento de desmantelar el Derecho Laboral, es decir: que el trabajador sea desechable ${ }^{165}$. Obviamente no todos los economistas comparten esta visión tan ideológica. Por ejemplo, varios economistas laborales han hecho presente que no existe evidencia segura (los resultados son ambiguos y fragmentados) acerca del efecto de las normas protectoras de los trabajadores y de los sindicatos en relación con el desempeño económico ${ }^{166}$.

Dado lo anterior, el Derecho Laboral se erige como una verdadera maldición para el AED, porque todas sus predicciones fallan. Si lo que plantean Richard Epstein y Richard Posner fuera cierto, Montana que desde 1987 estableció por ley la justa causa debiera estar en una grave crisis económica. Sin embargo, en ese Estado ha crecido sostenidamente el empleo en los primeros veinte años de aplicación de la ley protectora ${ }^{167}$.

Si fuera cierto lo que el AED dice de las regulaciones y del Derecho Laboral, la comparación entre Estados Unidos, Francia, Alemania, Canadá y los Países Escandinavos debiera ser devastadora. Todos estos países, salvo Estados Unidos, desde hace más de setenta años tienen un derecho laboral individual y colectivo protector y no se aprecian en crisis económica terminal, o que hayan dejado de ser desarrollados e, incluso, tienen muchos menos pobres que Estados Unidos. Es decir, si el AED tuviera razón, por algún extraño encantamiento (parafraseando a Miguel de Cervantes) estas leyes inflexibles de la economía no se les aplican o no funcionan en dichos países.

\section{Perspectiva ética}

Por último, desde una visión valórica, James Bowman y Jonathan West han analizado el employment at will desde una perspectiva ética. En su trabajo comparan la soberanía del empleador para despedir a voluntad con la doctrina de la soberanía en el sector público, donde el empleo era un privilegio y no un derecho. Este sistema de empleo público a voluntad

trescientas cuarenta y cuatro veces. Véase SANDEL (2011), p. 28. Thomas Piketty denomina a los gerentes en general como "supermanagers", en especial en los países anglosajones por sus abultados, excesivos y desproporcionales salarios respecto de los demás trabajadores. Véase PiketTy (2014), p. 315 y ss. En idéntico sentido, Adam Goldstein en Estados Unidos destaca que los despidos, las fusiones, la informatización y la política deliberada de desindicalización, han conllevado un aumento del número de directivos en las empresas y a un aumento exponencial de sus salarios. En otras palabras, esas medidas (antisindicales, entre otras) que supuestamente favorecerían a los accionistas han fortalecido a una nueva casta de managers cada vez más ricos. Véase Goldstein (2012).

${ }^{165}$ Harvey (2007), p. 185.

${ }^{166}$ Cahuc y Zylberberg (2004).

167 Véase n. 29 supra. 
para los servidores públicos, y predominante hasta el siglo XVIII, se basaba en los contactos políticos y no en el mérito, fomentando el favoritismo, el compadrazgo, la intimidación y la corrupción ${ }^{168}$. El sistema que lo reemplazó, el servicio civil basado en el mérito, supuso que los servidores públicos eran leales con el sistema de gobierno (guardianes morales de la democracia) y no con un partido político. Solo eran libres y honestos si su puesto estaba salvaguardado. La seguridad en el empleo público facilitaba un gobierno responsable y eficiente ${ }^{169}$.

Estos autores ocupan el "triángulo de la ética pública" (Svara) para analizar el empleo a voluntad, integrando las visiones de distintas escuelas éticas: teleológica (resultados esperados de la acción), deontológica (aplicación de las normas pertinentes) y ética de la virtud (integridad personal y carácter). La primera se identifica con la pregunta, ¿qué política produce mayor cantidad de bienestar para el mayor número?; la segunda con la pregunta, ¿desearía que los demás optaran por la misma decisión que he adoptado? y la tercera con, ¿ cómo actuaría una persona con integridad? ${ }^{170}$.

Desde una perspectiva teleológica, los defensores del employment at will sostienen que la posibilidad de perder el empleo motiva a los trabajadores. Los detractores del empleo a voluntad, por el contrario, señalan que existe evidencia consistente de que la estabilidad en el empleo va asociada con una alta productividad. Por otro lado, la estabilidad no obliga a mantener a un trabajador deficiente o cuando las condiciones económicas no lo permiten. En el contexto del trabajo, el miedo a perderlo es contraproductivo y se vincula con una pobre motivación del empleado, en afinidad con las nuevas técnicas blandas de recursos humanos. Su capacitación supone su permanencia en el trabajo. La vigencia del employment at will conlleva a que los trabajadores se pregunten: ¿̇si el empleador no es leal conmigo, por qué yo debo serlo con él? ${ }^{171}$.

Desde una óptica deontológica, los defensores del empleo a voluntad enfatizan los derechos de propiedad y sostienen que la justa causa disminuye la autonomía gerencial. En el contrato de trabajo ambas partes son libres de terminarlo cuando deseen, y lo han negociado sobre la base de sus intereses. Aunque puede haber abusos las deficiencias de la justa causa no son compensadas con sus virtudes ${ }^{172}$. Los defensores de la justa causa argumentan, por el contrario, que debe desconfiarse de cualquier concentración de poder, como la que permite el despido libre. James Bowman y

${ }^{168}$ Bowman y West (2007), pp. 119-120.

${ }^{169}$ Op. cit., p. 120. Estos autores se preguntan en su artículo si es conveniente volver a un sistema de despido libre en el sector público.

${ }^{170}$ Op. cit., p. 121.

${ }^{171}$ Op. cit., pp. 122-123.

172 Op. cit., p. 123. 
Jonathan West citan en la introducción a su trabajo las palabras de Lord Acton: "el poder tiende a corromperse y el poder absoluto conlleva la corrupción absoluta" ${ }^{173}$. En el contrato de trabajo la autonomía está en peligro, porque es evidente que el trabajador necesita el empleo mucho más que el empleador al trabajador. Los empleadores controlan los medios de producción, sin los cuales no puede laborar el empleado, por tanto, los primeros se encuentran en una situación dominante ${ }^{174}$. En este contexto, la seguridad en el trabajo (justa causa) es clave para nivelar a las partes. Las excepciones al empleo a voluntad son bastante limitadas, y el empleador mantiene un amplio poder para terminar el contrato por cualquier o ninguna causa. Como la mayoría de las personas necesita trabajar para vivir, es decir, se ven forzadas a trabajar, una verdadera autonomía resulta casi un imposible ${ }^{175}$. El despido libre afecta tanto a individuos como a las organizaciones, porque se traduce en una especie de licencia para tratar injustamente a la contraparte ${ }^{176}$.

Desde la visión de la ética como virtud, los defensores del employment at will argumentan que la relación de trabajo sin regulaciones que estorben fomentan la integridad de las partes ${ }^{177}$. La libertad de contrato y el laissez faire es lo que mejor asegura la confianza entre las partes. Los defensores de la justa causa señalan, por el contrario, que si el trabajador sabe que será tratado en forma justa tiene incentivos para ser íntegro. Por el contrario, el empleo a voluntad no fomenta la integridad, porque son pocos las motivaciones para que un subordinado denuncie una conducta fraudulenta de sus jefes si sabe que puede ser despedido, incluso, por ninguna causa. No hay incentivo para criticar las políticas ineficientes o poco éticas si el despido es libre. Es más, puede ser tentado a participar en políticas dudosas con tal de no perder su empleo. El poder absoluto puede corromper absolutamente. Con el employment at will el decir la verdad, algo tan importante para la integridad, se devalúa ${ }^{178}$.

James Bowman y Jonathan West concluyen que todo poder debe ser contenido y que una relación laboral con pocas obligaciones recíprocas,

${ }^{173}$ Lord Acton citado por Bowman y West, (2007) p. 119.

${ }^{174}$ Quien mejor para describir la precariedad del trabajador que Adam Smith: "Un terrateniente, un granjero, un industrial o un mercader, aunque no empleen un solo obrero, podrían en general vivir durante un año o dos del capital que ya han adquirido. Pero sin empleo muchos trabajadores no podrían resistir ni una semana, unos pocos podrían hacerlo un mes y casi ninguno un año. A largo plazo el obrero es tan necesario para el patrono como el patrono para el obrero, pero esta necesidad no es así a corto plazo". Véase Sмiтh (2011), p. 111.

${ }^{175}$ Bowman y West (2007), p. 125.

${ }^{176}$ Op. cit., p. 125.

177 Op. cit., p. 126.

178 Op. cit., p. 126. 
donde el empleador tiene muy pocas obligaciones respecto del trabajador, compromete el bienestar, el deber y la integridad personal ${ }^{179}$.

\section{Conclusiones}

Concordando con los autores citados y parafraseando a Charles Fried, los resultados del empleo a voluntad son intolerables. Y Richard Epstein le da la razón con elocuentes palabras, aunque intentaba defender el employment at will: "el despido es poco frecuente dado que la amenaza de despido es efectiva" 180 . Un contratante jamás debiera estar sujeto a la coacción permanente de su contraparte $y$, de ser así, ello nunca debiera estar amparado por el Derecho.

Para el AED tanto el empleador como el trabajador se encuentran en igualdad de condiciones. Por el contrario, casos como Bammert, Bullard y Nelson nos recuerdan la realidad del contrato de trabajo. En esta materia, la noción formalista de libertad puede tener consecuencias devastadoras, como decía Anatole France: "Las leyes, ... prohíben a ricos y pobres dormir bajo los puentes, mendigar en las calles y robar pan de molde" 181 .

Hemos visto cómo surge esta doctrina y cuáles serían sus justificaciones. Salvo algunos defensores del AED, los laboralistas estadounidenses están en contra de una tesis que supone una igualdad contractual entre las partes. Y aun, autores que no son laboralistas han defendido límites al despido libre, como Roscoe Pound o Cass Sunstein, además de los argumentos visionarios del juez Oliver Wendell Holmes Jr.

Es un hecho que, a diferencia de lo que señala Richard Epstein, para el trabajador es mucho más complicado perder su empleo que para el empleador prescindir de un trabajador. Se trata de una realidad común a cualquier sistema capitalista. Por ello, en todos los países e, incluso, en Estados Unidos hay numerosas leyes que velan por las normas de higiene y seguridad en el trabajo, porque no haya acoso al empleado y tampoco acoso sexual. ¿’Por qué? Porque para el trabajador no es fácil cambiar de trabajo. Necesita su sustento y generalmente su familia depende también de los adultos que trabajan. Y es por esto que a nadie preocupa el acoso sexual inverso: del trabajador al empleador, porque este último detenta el poder en la relación e, incluso, en los sistemas con justa causa, puede despedir al trabajador que intenta un avance sexual no consentido en su contra. Por el contrario, la misma situación respecto del trabajador es un verdadero drama.

\footnotetext{
${ }^{179}$ Bowman y West (2007), p. 128.

${ }^{180}$ EPSTEIN (1984), p. 974.

${ }^{181}$ Citado por Zimmer (2013), p. 2.
} 
Hablar de despido a voluntad o libre alude a la idea de libertad y de poder, en un contrato que se basa en una relación de poder, como el de trabajo. Poder reconocido por el Derecho Laboral, en la facultad de dirección del empleador y en la subordinación del empleado, y que justifica que se trate de un contrato dirigido por el legislador ${ }^{182}$. Y el poder se manifiesta en la incertidumbre de quien está bajo el poder ajeno ${ }^{183}$. Es el empleador quien maneja la incertidumbre del trabajador y el empleo a voluntad es un instrumento privilegiado en este sentido, como nos lo recuerdan los casos Bammert, Bullard y Nelson.

En este contexto no es de extrañar que todos los países con economía de mercado limiten el despido, porque como manifestaba lord Acton el poder sin control es corrupción. La excepción y el caso anómalo es justamente el de Estados Unidos.

Finalizaremos afirmando, entonces, que un sistema de despido libre contraviene frontalmente los principios del Derecho Laboral defendidos por la doctrina latinoamericana, y que desde la perspectiva anglosajona, el empleo a voluntad erosiona de igual forma la idea protectora del Derecho Laboral. Además, las críticas a la justa causa del AED no se sustentan ni en un conocimiento técnico ni en la realidad del contrato de trabajo. Incluso, como hemos visto, desde una perspectiva ética resulta inadmisible el poder privilegiado del empleador cuando la regla es el despido libre.

\section{Bibliografía CITADA}

Ackerman, Mario E. (2005). "Los Principios en el Derecho del Trabajo”, en Mario E. Ackerman (dir.) y Diego M. Tosca (coord.). Tratado de Derecho del Trabajo. Buenos Aires: Rubinzal-Culzoni Editores. Tomo I.

Arnow-Richman, Rachel (2016). "Modifyng At-Will Employment Contracts". Boston College Law Review. Vol. 57. Boston.

Arnow-Richman, Rachel (2010). "Just Notice: Re-Reforming Employment-atWill”. UCLA Law Review. Vol. 58. Los Angeles.

Arufe Varela, Alberto (2009). "El voto particular del juez Oliver Wendell Holmes, Jr. en el caso Coppage v. Kansas (1915). Un texto jurídico norteamericano clásico contra el libre despido". Anuario Coruñés de Derecho Comparado del Trabajo. Vol. I. La Coruña.

Atleson, James (1997). "Confronting Judicial Values: Rewriting the Law of Work in a Common Law System". Buffalo Law Review. Vol. 45. New York.

${ }^{182}$ Gamonal (2015), pp. 37-43 y 75-77, y Gamonal (2014), pp. 1-50.

${ }^{183}$ Michel Crozier citado por Bauman (2007), p. 61 y ss. 
Barbagelata Héctor-Hugo (2009). El Particularismo del Derecho del Trabajo y los Derechos Humanos Laborales. Montevideo: Fundación de Cultura Universitaria.

Bauman, Zygmunt (2007). Libertad. Buenos Aires: Losada.

Befort, Stephen F. \& John W. Budd (2009). Invisible Hands, Invisible Objetives. Stanford: Stanford University Press.

Bierman, Leonard \& Stuart A. Youngblood (1984). "Employment-at-Will and the South Carolina Experiment”. Industrial Relations Law Journal. Vol. 7. Oxford.

Bird, Robert C. \& Donald J. Smythe (2008). "The Structure of American Legal Institutions and the Diffusion of Wrongful-Discharge Laws, 1978-1999". Law \& Society Review. Vol. 42. No 4. Hoboken.

BlADES, Lawrence E. (1967). "Employment At Will vs. Individual Freedom: On Limiting the Abusive Exercise of Employer Power". Columbia Law Review. Vol. 67. New York.

Bowman, James S. and Jonathan P. West (2007). "Lord Acton and Employment Doctrines: Absolute Power and the Spread of At-Will Employment". Journal of Business Ethics. Vol. 74. New York.

Cahuc, Pierre \& André Zylberberg (2004). Labor Economics. Cambridge: MIT University Press.

Calabresi, Guido (2011). "Prefacio", en Un vistazo a la catedral. Lima: Palestra.

CHAng, Ha-Joon (2012). 23 cosas que no te cuentan sobre el capitalismo. Barcelona: Debate.

Chemerinsky, Erwin (2014). The Case Against the Supreme Court. New York: Penguin Books.

Cohen, Amy J. (2009). "Revisitng Against Settlement: Some Reflection on Dispute Resolution and Public Value". Fordham Law Review. Vol. 78. New York.

Colander, David (2001). The Lost Art of Economics. Essays on Economics Profession. Cheltenham: Edward Elgar.

Coluins, Hugh (1989). "Labour Law is a Vocation". Law Quarterly Review. Vol. 105. London.

Compa, Lance (2014). "Not Dead Yet: Preserving Labor Law Strengths While Exploring New Labor Law Strategies”. UC Irvine Law Review. Vol. 4. California.

Corbett, William R. (2013). "An Outrageous Response to 'You're fired'”. North Carolina Law Review. Vol. 92. North Carolina.

Cox, Archibald (1956-1959). "Labor Law and the American Constitution". The University of Queenslad Law Journal. Vol. 3. Brisbane.

Davidov, Guy (2014). "The Goals of Regulating Work: Between Universalims and Selectivity". University of Toronto Law Journal. Vol. 1. Toronto.

Davidov, Guy \& Brian Langille (eds.) (2011). The Idea of Labour Law. Oxford: Oxford University Press.

Davies, Anne (2009). Perspectives on Labour Law. Cambridge: Cambridge University Press).

Deakin, Simon \& Morris, Gillian S. (2009). Labour Law. Portland: Hart Publishing. 
Deakin, Simond \& WiLkinson, Frank (1994). "Rights vs Efficienty? The Economic Case for Transnational Labour Standards". Industrial Law Journal. Vol. 23. $\mathrm{N}^{\mathrm{O}} 4$. Oxford.

Edelman, Lauren B., Steven E. Abraham \& Howard S. Erlanger (1992). "Professional Construction of Law: The Inflated Threat of Wrongful Discharge". Law \& Society Review. Vol. 26. Hoboken.

England, Geoffrey (2008). Individual Employment Law. Toronto: Irwin Law.

Epstein, Richard (2011). On Liberty. Cambridge: Harvard University Press.

Epstein, Richard (1984). "In Defense of the Contract at Will". The University of Chicago Law Review. Vol. 51. Chicago.

Ermida Uriarte, Óscar (2011). Meditación sobre el Derecho del Trabajo. Montevideo: Cuadernillos de la Fundación Electra.

EstLund, Cynthia (2002). "How Wrong Are Employees About their Rights and Why Does it Matter?". New York University Law Review. Vol. 77. New York.

EstLund, Cynthia (1996). "Wrongful Discharge Protections in an At-Will World". Texas Law Revierw. Vol. 74. Austin.

Estreicher, Samuel y Cherry, Miriam (2008). Global Issue in Employment Law. St. Paul: Thomson West.

Ewing, Bradley T., Charles M. North \& Beck A. Taylor (2005). "The Employment Effects of a "Good Cause" Discharge Standard in Montana". Industrial and Labor Relations Review. Vol. 59. $\mathrm{N}^{\circ} 1$. Ithaca.

Feinman, Jay M. (1991). "The Development of the Employment-at-Will Rule Revisited". Arizona State Law Journal. Vol. 23. Phoenix.

Feinman, Jay M. (1976). "The Development of the Employment at Will". The American Journal of Legal History. Vol. xx. Philadelphia.

Fiss, Owen (2007). “Contra la Conciliación”, en Owen M. Fiss. El derecho como razón pública. (trad. Esteban Restrepo Saldarriasa), Madrid: Marcial Pons.

Fourcade, Marion, Etienne Ollion \& Yann Algan (2015). "The Superiority of Economists". Journal of Economic Perspectives. Vol. 29. $\mathrm{N}^{\circ} 1$. Nashville.

Frankfurter, Felix (1927). "Mr. Justice Holmes and the Constitution. A Review of his Twenty-Five Years on the Supreme Court". Harvard Law Review. Vol. 41. Cambridge USA.

Freed, Mayer G. \& Daniel D. Polsby (1990). "The Doubtful Provenance of "Wood's Rule" Revisited”. Arizona State Law Journal. Vol 22. Phoenix.

FrIed, Charles (1984). "Individual and Collective Rights in Work Relations: Reflections in the Current State of Labor Law and its Prospects". The University of Chicago Law Review. Vol. 51. Chicago.

Galiana Moreno, Jesús M. (1978). El contrato de trabajo en el Derecho Inglés, Barcelona: Bosch.

Gamonal Contreras, Sergio (2015). La eficacia diagonal u oblicua y los estándares de conducta en el Derecho del Trabajo. Santiago: La Ley Thomson Reuters. 
Gamonal Contreras, Sergio (2014). Fundamentos de Derecho Laboral. Santiago: La Ley Thomson Reuters.

Gamonal C., Sergio y César Rosado Marzán (2014a). El principio de protección del trabajador en el Derecho Norteamericano. Santiago: Thomson Reuters La Ley.

Gamonal C., Sergio \& César Rosado Marzán (2014b). "Protecting Workers as a Matter Principle: A Latin American Views of U.S. Work Law". Washington University Global Studies Law Review. Vol. 13. No 4. Saint Louis.

Gamonal Contreras, Sergio (1998). Introducción al Derecho del Trabajo. Santiago: ConoSur.

Goldstein, Adam (2012). "Revenge of the Managers: Labor Cost-Cutting and the Paradoxical Resurgence of Managerialism in the Shareholder Value Era, 1984-2001". American Sociological Revue. 2012. Vol. 77. Thousand Oaks.

Hacker, Jacob S. \& Paul Pierson (2011). Winner-Take-All Politics. Nueva York: Simon \& Schuster Paperbacks.

HARVARD Law Review (1980). "Note. Protecting At Will Employees Against Wrongful Discharge: The Duty to Terminate Only in Good Faith". Harvard Law Review. Vol. 93. Cambridge USA.

Harvey, David (2007). Breve historia del neoliberalismo. Madrid: Ediciones Akal.

Hazard, Geoffrey C. \& Paul D. ScotT, (1988). "The Public Nature of Private Adjudication”. Yale Law \& Policy Review. Vol. 6. New Haven.

Hogler, Raymond L. (1985). "Employment at Will and Scientific Management: The Ideology of Workplace Control”. Hofstra Labor Law Journal. Vol. 3. New York.

Kennedy, Duncan (1981). "Critical Labor Theory: A Comment”. Industrial Relations Law Journal. Vol. 4. Berkeley.

KLARE, Karl (1981). "Labor Law as Ideology: Towards a New Historiography of Collective Bargaining Law”. Industrial Relations Law Journal. Vol. 4. Berkeley.

KLARE, Karl (1978). "Judicial Deradicalization of the Wagner Act and the Origins of Modern Legal Consciousness, 1937-1941”. Minnesota Law Review, Vol. 62, $\mathrm{N}^{\mathrm{O}}$ 3. Minneapolis.

LAMbert, Edouard (2010). El gobierno de los jueces. Madrid: Tecnos.

Macaulay, Steward (1985). "Una visión empírica del contrato". Revista Chilena de Derecho. Vol. 12. Santiago.

Macchiavello, Guido (1986). Derecho del Trabajo. Santiago: Fondo de Cultura Económica.

Mallor, Jane P. (1985). "Punitive Damages for Wrongful Discharge of At Will Employees". William and Mary Law Review. Vol. 26. Williamsburg.

Martínez Girón, Jesús y Alberto Arufe Varela (2007). Fundamentos de Derecho comunitario y comparado, europeo y norteamericano, del Trabajo y de la Seguridad Social. Oleiros: Netbiblo.

Martínez Girón, Jesús (1988). El despido en el Derecho de los Estados Unidos. Madrid: Civitas.

Mayer, Thomas (2006). Economia: ¿verdad o precisión? Madrid: Marcial Pons. 
McGinley, Ann C. (1996). "Rethinking Civil Rights and Employment at Will: Toward a Coherent National Discharge Policy". Ohio State Law Journal. Vol. 57. $\mathrm{N}^{\mathrm{O}}$ 5. Columbus.

Morriss, Andrew P. (2007). "The Story of the Montana Wrongful Discharge from Employment Act: A Drama in 5 Acts", in Samuel Estreicher \& Gillian LESTER (eds.). Employment Law Stories. Nueva York: Thomson West.

Moss, Scott A. (2005). "Where there's At-Will, There are Many Ways: Redressing the Increasing Incoherence of Employment at Will". University of Pittsburgh Law Review. Vol. 67. Pittsburgh.

O'NEILL, Martin (2013). "Economics after the crisis, and the crisis in economics". Renewal. Vol. 21. N ${ }^{\circ}$ 2-3. London.

Oviatt, Nancy L. (1986). "The Status of the Wrongful Discharge Cause of Action in South Dakota". South Dakota Law Review. Vol. 31. Vermillion.

PiketTy, Thomas (2014). Capital in the twenty-first Century. Cambridge: The Belknap Press of Harvard University Press.

Plá Rodríguez, Américo (1998). Los principios del Derecho del Trabajo. Buenos Aires: Depalma.

Posner, Richard (2007). El análisis económico del Derecho. México: Fondo de Cultura Económica.

Posner, Richard (1984). "Some Economics of Labor Law". The University of Chicago Law Review. Vol. 51. Chicago.

Pound, Roscoe (1908-1909). "Liberty of Contract". Yale Law Journal. Vol. 18. New Haven.

Ray, Douglas E., Calvin William Sharpe \& Robert N. StRassfeld (2011). Understanding Labor Law. San Francisco: LexisNexis.

SAndeL, Michael J. (2011). Justicia. ¿Hacemos lo que debemos? Barcelona: Debate.

Schwab, Stewart J. (1993). "Life-Cycle Justice: Accomodating Just Cause and Employment At Will”. Michigan Law Review. Vol. 92. Ann Arbor.

SEn, Amartya (2011). Sobre Ética y Economía. Madrid: Alianza Editorial.

Shapiro, J. Peter y Tune, James F. (1974). "Notes. Implied Contract Right to Job Security". Stanford Law Review. Vol. 26. Stanford.

Smith, Adam (2011). La Riqueza de las Naciones. Madrid: Alianza Editorial.

Smith, Peggie E., Ann C. Hodges, Susan J. Stabile \& Rafael Gely (2009). Principles of Employment Law. St. Paul: West.

St. Antoine, Theodore J. (1992). "The Model Employment Termination Act: Fairness for Employees and Employers Alike”. Labor Law Journal. Vol. 43. August. Riverwoods.

Steidle, Barbara C. (1999). "Adair v. United States", en Kermit L. Hall (ed.). The Oxford Guide to United States Supreme Court Decisions. New York: Oxford University Press.

StEMPEL, Jeffrey W. (1991). "Reconsidering the Employment Contract Exclusion in Section 1 of the Federal Arbitration Act: Correcting the Judiciary's Failure of Statutory Vision”. Journal of Dispute Resolution. Vol. 1991. N 2. Columbia. 
Sternlight, Jean R. (2002). "Is the U.S. out of the Limb? Comparing the U.S. Approach to Mandatory Consumer and Employment Arbitration to that of the Rest of the World". University of Miami Law Journal. Vol. 56. Miami.

Stone, Katherine V.W. (2013). "The Decline of the Standard Contract of Employment in the United State", in Katherine V.W. Stone y Harry Arthurs (eds.). Rethinking Workplace Regulation. Beyon the Standard Contract of Employment. New York: Russel Sage Foundations.

Summers, Clyde (2001). "Individualism, Collectivism and Autonomy in American Labor Law". Employee Rights and Employment Policy Journal. Vol. 5. Chicago.

Summers, Clyde (2000). "Employment at will in the United State: The Divine Right of Employers". University of Pennsylvania Journal of Labor and Employment Law. Vol. 3. Philadelphia.

Summers, Clyde (1988). "Labor Law as the Century Turns: A Changing of the Guard”. Nebraska Law Review. Vol. 67. Lincoln.

Summers, Clyde (1976). "Individual Protection Against Unjust Dismissal: Time for Statute", Virginia Law Review. Vol. 62. Charlottesville.

Sunstein, Cass R. (1984). "Rights, Minimal terms, and Solidarity: A Comment". The University of Chicago Law Review. Vol. 51. Chicago.

SupIOT, Alain (2007). Homo Juridicus. Ensayo sobre la función antropológica del derecho. Buenos Aires: Siglo XXI Editores.

Tucker, Eric (2010). "Renorming Labour Law: Can We escape Labour Law's Recurring Regulatory Dilemmas?”. Industrial Law Journal. Vol. 39. N 2. Oxford.

Ugarte Cataldo, José Luis (2001). Análisis Económico del Derecho. El derecho laboral y sus enemigos. Montevideo: Fundación de Cultura Universitaria.

WeILER, Paul C. (1993). Governing the Workplace. The future of Labor and Employment Law. Cambridge: Harvard University Press.

Wood, Stephen B. (1999). "Hammer v. Dagenhart", Kermit L. Hall (ed.). The Oxford Guide to United States Supreme Court Decisions. New York: Oxford University Press.

Young, Donna E. (2001). "Racial Releases, Involuntary Separations, and Employment at Will". Loyola of Los Angeles Law Review. Vol. 34. Los Angeles.

Zimmer, Michael (2013). "Inequality, Individualized Risk, and Insecurity". Wisconsin Law Review. Vol. 1. Madison.

\section{Sentencias citadas}

Sentencias de Estados Unidos

Adair v. United State (CS Federal), 1908, 208 U.S. 161, Steidle (1999).

Agos v. Howard Johnson Co. (CS Mass.), 1976, 355 N.E.2d 315, 318-319, RAY et al. (2011).

Bammert v. Don'S Super Valu, INC. (CS Wis.), 2002, 646 N.W.2d 365, 369-70, Moss (2005). 
Bigelow v. Bullard (CS Nev.), 1995, 901 P. 2d 630, McGinley (1996).

Coppage v. Kansas, (CS Federal), 1915, U.S. No 236, LAMbert (2010).

Fortune v. NCR, 373 (CS Mass.), 1977, 96, 364 N.E.2d 1251, Sмiтн et al. (2009).

Hammer v. Dagenhart, (CS Federal), 1918, 247 U.S. 251, Frankfurter (1927).

Hitchman Coal and Coke c ${ }^{\circ}$ v. Mitcheell an al (CS Federal) 1917, U.S. N ${ }^{\circ} 245$, LAMBERT (2010).

Martin v. New York Life Insur. Co. (CS NY), 1895, 148 N.Y. 117, 42 N.E. 416, FEINMAN (1976).

Nelson v. James H. Knight DDS, P.C. (CS Iowa), 2013, 834 N.W.2d 64, 66, CORBETt (2013).

Payne v. Western \& Atl. R.R. (CS Tenn.), 1884, 81 Tenn. 507, 518, Schwab (1993).

Pertemann v. International Brotherhood of Teamsters (CA Cal.), 1959, 174 Cal. App. 2d 184, 29 Cal. Rptr. 399, 344 P.2d 25, Bierman y Youngblood (1984).

Pugh v. See's Candies, Inc. (CA Cal.), 1981, 116 Cal. App. 3d 311, RAY et al. (2011).

St. Mary's Honor Center v. Hicks (CS Federal) 1993, 509 U.S. 502, McGinleY (1996).

United State v. Darby Lumber Co. (CS Federal), 1941, 312 U.S. 100, Wood (1999).

Visser v. Packer Engineering Associates, Inc. (CA $7^{\text {th }}$ Cir.), 1991, 924 F.2d 655, McGinley (1996).

Sentencias de Gran Bretaña

Fairman v. Oaford, 1860, 5 H.\&N. 635, Galiana (1978). 